Central Washington University

ScholarWorks@CWU

All Faculty Scholarship for the College of the Sciences

$4-17-2012$

Bulk rock composition and geochemistry of olivine-hosted melt inclusions in the Grey Porri Tuff and selected lavas of the Monte dei Porri volcano, Salina, Aeolian Islands, southern Italy.

Angela L. Doherty

Robert J. Bodnar

Benedetto De Vivo

Wendy A. Bohrson

Harvey E. Belkin

See next page for additional authors

Follow this and additional works at: https://digitalcommons.cwu.edu/cotsfac

Part of the Geochemistry Commons, Geology Commons, Geophysics and Seismology Commons, and the Volcanology Commons 
Authors

Angela L. Doherty, Robert J. Bodnar, Benedetto De Vivo, Wendy A. Bohrson, Harvey E. Belkin, Antonia Messina, and Robert J. Tracy 


\title{
Bulk rock composition and geochemistry of olivine-hosted melt inclusions in the Grey Porri Tuff and selected lavas of the Monte dei Porri volcano, Salina, Aeolian Islands, southern Italy.
}

\author{
Angela L. Doherty ${ }^{1,2,3 *}$, Robert J. Bodnar², Benedetto De Vivo ${ }^{3}$, Wendy A. Bohrson ${ }^{4}$, Harvey E. \\ Belkin $^{5}$, Antonia Messina ${ }^{1}$, Robert .J. Tracy ${ }^{2}$ \\ 1 Dipartimento di Scienze degli Alimenti e dell'Ambiente "Prof. G. Stagno d'Alcontres" - Sezione Scienze della Terra, \\ Università degli Studi di Messina. Messina 98122, Italy \\ 2 Fluids Research Laboratory, Department of Geosciences, Virginia Tech, Blacksburg VA 24060 USA \\ 3 Dipartimento di Scienza della Terra, Università degli Studi di Napoli Federico II, Napoli, 80134 Italy \\ 4 Department of Geological Sciences, Central Washington University, Ellensburg, WA 98929 USA \\ 5 U.S. Geological Survey, 956 National Center, Reston, VA 20192 USA
}

Received 13 November 2011 ; accepted 28 March 2012

\begin{abstract}
The Aeolian Islands are an arcuate chain of submarine seamounts and volcanic islands, lying just north of Sicily in southern Italy. The second largest of the islands, Salina, exhibits a wide range of compositional variation in its erupted products, from basaltic lavas to rhyolitic pumice. The Monte dei Porri eruptions occurred between 60 ka and $30 \mathrm{ka}$, following a period of approximately 60,000 years of repose. The bulk rock composition of the Monte dei Porri products range from basaltic-andesite scoria to andesitic pumice in the Grey Porri Tuff (GPT), with the Monte dei Porri lavas having basaltic-andesite compositions. The typical mineral assemblage of the GPT is calcic plagioclase, clinopyroxene (augite), olivine $\left(\mathrm{FO}_{72-84}\right)$ and orthopyroxene (enstatite) \pm amphibole and Ti-Fe oxides. The lava units show a similar mineral assemblage, but contain lower Fo olivines ( $\left.\mathrm{Fo}_{57}-78\right)$. The lava units also contain numerous glomerocrysts, including an unusual variety that contains quartz, K-feldspar and mica. Melt inclusions (MI) are ubiquitous in all mineral phases from all units of the Monte dei Porri eruptions; however, only data from olivine-hosted MI in the GPT are reported here. Compositions of MI in the GPT are typically basaltic (average $\mathrm{SiO}_{2}$ of $49.8 \mathrm{wt} \%$ ) in the pumices and basaltic-andesite (average $\mathrm{SiO}_{2}$ of $55.6 \mathrm{wt} \%$ ) in the scoriae and show a bimodal distribution in most compositional discrimination plots. The compositions of most of the MI in the scoriae overlap with bulk rock compositions of the lavas. Petrological and geochemical evidence suggest that mixing of one or more magmas and/or crustal assimilation played a role in the evolution of the Monte dei Porri magmatic system, especially the GPT. Analyses of the more evolved mineral phases are required to better constrain the evolution of the magma.
\end{abstract}

Keywords: Salina $\cdot$ Aeolian Islands $\cdot$ melt inclusions $\cdot$ magmatic evolution

(C) Versita sp. z o.o. 


\section{Introduction}

Melt inclusions (MI) are droplets of melt that are trapped in mineral phases during crystal growth and are the magmatic equivalent of fluid inclusions [1]. MI are a powerful tool for understanding the magmatic evolution of a volcanic system, primarily because $\mathrm{MI}$ are isolated from the melt after entrapment, providing a "snapshot" of conditions in the magma chamber at the time of trapping. Comparisons of the mineral and bulk rock compositions of the host rocks and their $\mathrm{Ml}$ can provide insights into the evolution of the magmatic system, e.g. minimum depths and pressures of crystallisation, the tectonic setting for the origin of magmas, their magmatic evolution (whether they are a result of pure fractional crystallisation or if crustal assimilation or magma mixing played a role), as well as storage and residence times and ascent rates of magmas [1-10].

This paper presents results of a study of 39 naturally quenched $\mathrm{MI}$ in olivine from the Grey Porri Tuff unit of the Monte dei Porri volcano on the Aeolian Island of Salina, which is located in the Tyrrhenian Sea north of Sicily (Figure 1). Olivine-hosted MI were selected preferentially over pyroxene and feldspar-hosted $\mathrm{Ml}$ to constrain conditions during the early stages of magma evolution [7]. Additionally, olivine is relatively incompatible with many of the trace elements commonly used to infer sources and processes associated with magma evolution, thus reducing the possibility of diffusive equilibration between the trapped $\mathrm{Ml}$ and host mineral [7].

In most cases, the origin of the phases and therefore the nomenclature required in their description (i.e. whether they are phenocrysts, xenocrysts or antecrysts as described by Jerram and Martin [11]) is unclear. For reasons described below, it is apparent that the Monte dei Porri products contain populations of each crystal type. Some phases may be phenocrysts, having nucleated and grown in the same liquid that now represents the groundmass of their host-unit; some may be antecrysts, having been reincorporated into a melt from one of the melt progenitors; and some xenocrysts, having nucleated and grown in a different magma, but introduced into the current melt through a range of physical processes [11]. Such determinations could only be made through detailed isotopic and trace element analysis, which is beyond the scope of this study. As such, the term antecryst will be used to describe all mineral phases. Future studies are planned to determine the trace and volatile element chemistry of the $\mathrm{MI}$ and to examine $\mathrm{MI}$ hosted in other mineral phases. These data will allow us to better understand the evolution of the Monte dei Porri system and the origin of the Monte dei Porri parental magmas. Here, we compare MI compositions to bulk rock and mineral compositions from the GPT, and 5 lava samples from Monte dei Porri. This study presents the initial results from a larger project encompassing trace and volatile element compositions of $\mathrm{Ml}$ reported here, as well as $\mathrm{Ml}$ hosted in other mineral phases.

The Aeolian Islands were designated a World Heritage Site by UNESCO in 2000; in part, because of their great value as an outdoor volcanic laboratory [12]. While most MI studies of the Aeolian Islands have focussed on the currently or recently active volcanoes Stromboli and Vulcano (e.g. $[5,13-18]$ and others), there has been little study of MI from the older islands (especially those in the western part of the arc, Alicudi, Filicudi and Salina).

While the island of Salina is often referred to in studies of the general geochemistry of the Aeolian Arc [13, 19-23] (and others) most of this work as well as studies of Salina itself [24-26], have focussed on the largest and most chemically diverse volcano on the island, Fossa delle Felci. Other studies focussed on the dynamics and formation of the rhyolitic explosion crater, Pollara, where the unusual occurrence of a silicic body intruding a basaltic magma chamber and triggering an eruption is observed [27-30]. MI studies on Salina have been confined to quartz-rich crustal xenoliths in lavas from Monte dei Porri [10]. Some of the glomerocrysts studied here may also be crustal xenoliths as discussed in more detail below. The work by Zanon and Nikogosian [10], and similar studies from other Aeolian Islands [22, 31-33], suggest that crustal assimilation played a role in the evolution of Salina and other islands in the Aeolian arc.

\subsection{Geological Background}

Lying approximately $30 \mathrm{~km}$ north of the Island of Sicily, Salina is the second largest of the Aeolian Islands, which represent the surface expression of an arcuate chain of volcanic islands and submarine seamounts in the South Tyrrhenian Sea (Figure 1). The arc developed atop a block of continental crust, along the northern and western regions of the Calabro-Peloritani continental margin. It consists of both Tethyan oceanic and Proterozoic/Paleozoic continental crust covered by Meso-Cenozoic rocks, recently interpreted as originating from the delamination of a Jurassic-Cretaceous Mesomediterranean Microplate [34-42]. Volcanism in the arc began as early as 1.3 Ma [43] at the Sisifo seamount in the north-west of the arc and continues presently on the islands of Stromboli and Vulcano. A steeply dipping Benioff zone that is related to the collision of the African and Eurasian tectonic plates occurs beneath the eastern sectors of the arc, based on analysis of deepfocus earthquakes $[44,45]$. While most workers believe 
volcanism in the area is mainly a result of subductionrelated processes, e.g. [44, 46-48], evidence suggests that subduction is in a late-stage of evolution and that regional extensional tectonics may play a role in recent volcanism [49]. The Tindari-Letojanni-Malta (TLM) line is a dextral strike-slip fault that extends from Salina in the northwest, through the island of Sicily, to the Malta Escarpment at its south-eastern end [46] (and references therein), [50].

Peccerillo [23] separated the subaerial arc into 3 sectors based on volcanic history, chemistry and underlying structural features. The products and geochemical affinities of the 3 sectors are described only briefly here, and a more detailed description can be found in Peccerillo [23]. The western arc consists of the islands of Alicudi, Filicudi and Salina, which developed along a W-E trending fault system. Volcanic products on these islands range from basalt to dacite and straddle the boundary between the calcalkaline and high- $K$ calc-alkaline fields. The central arc sector comprises the islands of Lipari and Vulcano, which formed atop the TLM line associated with volcanism occurring within the last $200 \mathrm{ka}$. These volcanoes produced a wide range of volcanic products, including lava flows and pyroclastic flows, with compositions including mafic to silicic calc-alkaline, shoshonitic and alkali-potassic compositions. The eastern sector comprises the islands of Panarea and Stromboli and contains eruptive products ranging from shoshonitic to calc-alkaline in composition. Andesites and dacite lava domes dominate Panarea, with minor flows and pyroclastic deposits, while products from Stromboli vary widely from basalt lava flows and scoriae deposits to dacite [23].

Salina is located at the northwest end of the TindariLetojanni-Malta line (Figure 1), and occupies an area of approximately $27 \mathrm{~km}^{2}$. The island is comprised of 6 main eruptive centres (Pizzo Corvo, Serro del Capo, Monte Rivi, Fossa delle Felci, Monte dei Porri and Pollara) that formed between 430-13 ka [20, 24-26]. Subaerial volcanic activity occurred during 2 cycles of volcanism [26]. The older cycle, between 430-127 ka, is thought to have produced the stratocones of Pizzo Corvo, Serro del Capo, Monte Rivi and Fossa delle Felci [26], of which only the Fossa delle Felci cone survives. These edifices produced mainly high-alumina basalts with Fossa delle Felci also producing late andesites and dacites. An erosional unconformity separates the first cycle from the second, which began at approximately 67 ka with the formation of the andesitic Monte dei Porri cone and ended with the rhyolitic explosions of Pollara at about 13 ka.

At $886 \mathrm{~m}$, Monte dei Porri is the second highest of the island's twin peaks (Fossa delle Felci reaches $968 \mathrm{~m}$ above sea level). Keller [22-26] describes the Monte dei Porri products as the Grey Porri Tuffs and Red Cinder Agglomerates, intercalated and interlayered (respectively) with two-pyroxene, low silica andesite lava flows.

The Grey Porri Tuffs (GPT) were deposited by a series of explosive eruptions at the beginning of the $2^{\text {nd }}$ volcanic cycle on Salina, at approximately $67 \mathrm{ka}$. Described by Keller [26] as one of the most explosive eruption cycles in the history of the Aeolian Islands, the GPT are a series of scoria and pumice lapilli beds interlayered with indurated ash-lapilli tuffs $[26,51]$. Flow units dominate exposures in close proximity to the vent, and air-fall units are found in more distal regions and areas blocked by topographic barriers (i.e., high on the flanks of Fossa delle Felci volcano and on the eastern side of the island). All beds also contain entrained lithic material of varying sizes and origins. Outcrops of the GPT are found on the neighbouring islands of Lipari and Panarea, and up to $\sim 25 \mathrm{~km}$ away in exposures at Capo Milazzo, on the northern coast of Sicily [51].

\subsection{Sample Locations}

Samples SAL10-4A, SAL10-4B and SAL10-4C were all collected from an outcrop of air-fall lapilli, dominated by scoriaceous material of the GPT that is located in a roadcut on an access road on the western flanks of Fossa delle Felci volcano, approximately $870 \mathrm{~m}$ above sea level (Figure 1). The density and vesicularity of the individual clasts varied within three horizons that were differentiated from each other mainly by clast size. Basement material was not present but all horizons contained a small amount of cognate lithic material that is composed almost exclusively of aphyric, grey lava. This scoriaceous layer is hereafter described as the GPT scoria unit.

Horizon A is dominated by moderately sorted, grey scoriaceous material, less than $2 \mathrm{~cm}$ in diameter that is supported by a large fraction of finer matrix material. The main minerals in the scoria clasts are (in order of decreasing abundance) olivine, pyroxene and plagioclase, and these clasts contain the most abundant (and largest) olivine crystals of any horizon at this exposure. The exact thickness of this unit could not be determined as the base of the outcrop was not exposed, but it is at least $50 \mathrm{~cm}$ thick based on the exposed portion.

Horizon B is approximately $8 \mathrm{~cm}$ thick and is also moderately sorted but contains smaller clasts (up to $1.5 \mathrm{~cm}$ in diameter) compared to horizon A. Like Horizon A, Horizon $B$ is also dominated by scoriaceous material supported by finer-grained matrix material. However, scoria clasts in this horizon contain less olivine compared to Horizon A and the mineral assemblage is dominated by pyroxene 


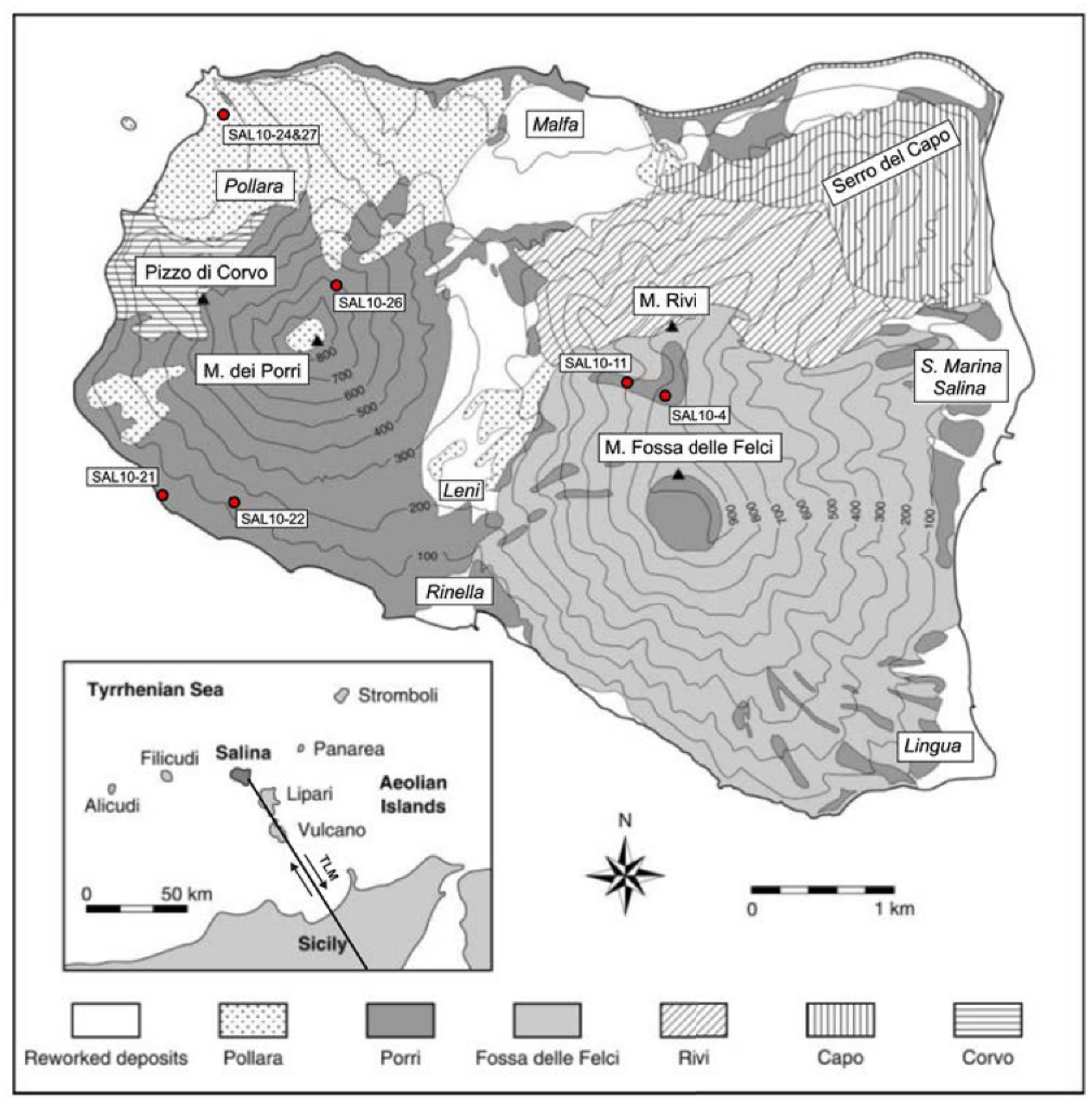

Figure 1. The island of Salina and its location in the Aeolian Arc (inset). Sample locations are indicated with red circles and names of towns are in italics. The Tindari-Letojanni-Malta Line is labelled "TLM" on the inset. Modified after Gertisser and Keller [25] (based on Keller [26]).

and plagioclase. The olivine is finer grained compared to Horizon A and is slightly altered.

Horizon $C$ is poorly sorted, and differs from the other two horizons in that it has a larger average clast size $1 \leq 3 \mathrm{~cm}$ in diameter) and contains lithic fragments $(\leq 4 \mathrm{~cm}$ in diameter). The scoria fragments in this horizon contain a large amount of olivine, always in association with titaniumiron oxides. Horizon $\mathrm{C}$ also contains pyroxene and some feldspar, similar to Horizons A and B. However, in this horizon, the ratio of feldspar to mafic phases was smaller compared to the other two horizons. The largest clasts of cognate lithic material were found in this horizon.

The scoria clasts contained approximately 10-20 vol \% antecryst. Minerals in all three horizons of SAL10-4 are typically euhedral in shape and occur as single crystals. However, multi-mineralic crystal glomerocrysts similar to those observed in the lavas are also present.
SAL10-11A and SAL10-11B were sampled from a roadcut further down the western flanks of Fosse delle Felci, along the same access road where samples SAL10-4A, B \& C were collected (Figure 1). This outcrop contained alternating layers of fine-grained welded tuff and pumiceous air-fall tephra and as well as a large amount of heterogeneous cognate lithic material. Two layers dominated by grey, lapilli-sized pumiceous material were sampled separately here because one horizon (Horizon A) had a distinctly higher proportion of lithic material, with some clasts up to $5 \mathrm{~cm}$ in diameter. As vesicularity and density varied between the individual clasts, the distinction between cognate lithic material and juvenile material was, at times, difficult, and care was taken in the selection of sample material from these horizons. Hereafter, this pumiceous layer will be referred to as the GPT pumice. 
Although none of the above samples were collected from the "type" locations for pumice-supported GPT material (along the northern coastline near Malfa (Figure 1), and the eastern coast between Santa Marina and Lingua (Figure 1) as described by Keller [26]), the outcrops that were sampled are identified as GPT by Keller on his most current geological map [26].

The pumices show a vitrophyric texture and contain much lower antecryst contents (approximately 5 vol \%) compared to the scoria units.

\subsection{Analytical techniques}

Five samples were collected from the Grey Porri Tuffs from road-cut exposures on the flanks of Fossa delle Felci (Two from location SAL10-11 and 3 from location SAL10-4). Care was taken to sample both the pumiceous and scoriaceous lapilli beds described by Keller [26] and Lucchi et. al [51]. Five additional samples were taken from different flows of the Monte dei Porri lavas from different positions around the volcano, in an effort to sample units ranging from the oldest to the youngest exposures on the island (Figure 1).

The GPT scoria and pumice material was first dried under heat at $\leq 37^{\circ} \mathrm{C}$ and juvenile clasts were then sorted from the bulk samples. Lava samples were trimmed using a rock saw to obtain fresh rock. This was particularly important for the older exposures as they were removed from the sea cliffs on the southern coast of the island and showed evidence of surface weathering.

Bulk rock compositions and trace element/REE abundances of samples of each unit, including the lavas and GPT material, were obtained by XRF and ICPMS analysis respectively, at Acme Analytical Laboratories Ltd. (Vancouver, Canada). Acme Analytical Laboratories reports the minimum detection limits for major oxides were $0.01 \mathrm{wt} \%\left(0.1 \mathrm{wt} \%\right.$ for $\left.\mathrm{SiO}_{2}\right)$ and $0.01 \mathrm{ppm}$ and above for trace elements based on comparisons between measured and published compositions of standard reference materials. Thin sections of each unit were prepared at Virginia Tech (Blacksburg VA, USA) for petrographic studies and polished "thick sections" were prepared from the lava units for electron microprobe analysis.

Pumice and scoria clasts were crushed by hand using a mortar and pestle, taking care to minimise fracturing of the crystals. The material was then passed through a series of sieves and the size fraction between $2.0-0.425 \mathrm{~mm}$ was reserved for crystal sorting. Olivine crystals were handpicked under a binocular microscope. Selected crystals were mounted individually on epoxy pegs approximately $0.7 \mathrm{~mm}$ in diameter (using conventional drinking straws as moulds) and polished using alumina powder following a method similar to that described in Thomas and Bodnar [52]. Because the crystals were relatively clear and free of fractures and solid inclusions, only one side of the crystal required polishing to study the MI in the crystal. Those crystals with glassy melt inclusions larger than $10 \mu \mathrm{m}$ were selected for analysis. After exposing the target $\mathrm{MI}$ by careful polishing, 21 crystals were loaded into one inch round, indium mounts in preparation for analysis.

After mounting, samples were carbon coated and the $\mathrm{MI}$ were checked for homogeneity by EDS imaging and elemental mapping using a Cameca SX-50 Electron Microprobe at Virginia Tech. The homogeneous glassy inclusions and antecryst phases of the tephras were then analysed for major elements using the same Cameca SX50 Electron Microprobe at Virginia Tech. An accelerating voltage of $15 \mathrm{keV}$ was used with a current of 10-20 nA using various diameter probe spots to minimise sodium loss in the plagioclase and glass analyses.

Additional electron microprobe analyses of major elements in feldspar, pyroxene and olivine from the lava samples were obtained at the U. S. Geological Survey in Reston, VA, with a JEOL JXA-8900R five spectrometer, fully-automated electron microprobe using wavelengthdispersive $X$-ray spectrometry. Analyses were made at an accelerating voltage of $15 \mathrm{keV}$, and a 20 or $30 \mathrm{nA}$ probe current, using various diameter probe spots depending on the phase being analysed to minimise sodium loss. The relative accuracy of the analyses, based upon comparison between measured and published compositions of standard reference materials, is $\sim 1-2 \%$ for concentrations $>1$ wt. \% and $\sim 5-10 \%$ for concentrations $<1$ wt. \% for analyses conducted at both the USGS and Virginia Tech.

\section{Sample Petrography}

Monte dei Porri lavas are porphyritic, with feldspar and pyroxene crystals up to $1 \mathrm{~mm}$ in length visible in hand specimen. The mineral assemblage consists of calcic plagioclase+clinopyroxene+olivine+orthopyroxene+ titanium-iron oxides \pm K-feldspar, mica and quartz. Kfeldspar, mica and quartz were generally only present within multi-mineralic glomerocrysts ranging up to $2 \mathrm{~mm}$ in length, which are observed in most lava samples (Figure 2A). Three types of glomerocrysts were identified in the Monte dei Porri lavas, and they are similar to those described by Zanon and Nikogosian [10]. The first and most common were mono- or multi-mineralic clusters of "magmatic" [10] assemblages (cpx+pla \pm olv \pm opx). Also present were rarer glomerocrysts with a more felsic assemblage (plag $+c p x+o p x+o l v \pm q t z \pm K-s p a r \pm m i c a)$. Least common were glomerocrysts with cumulate textures, with 


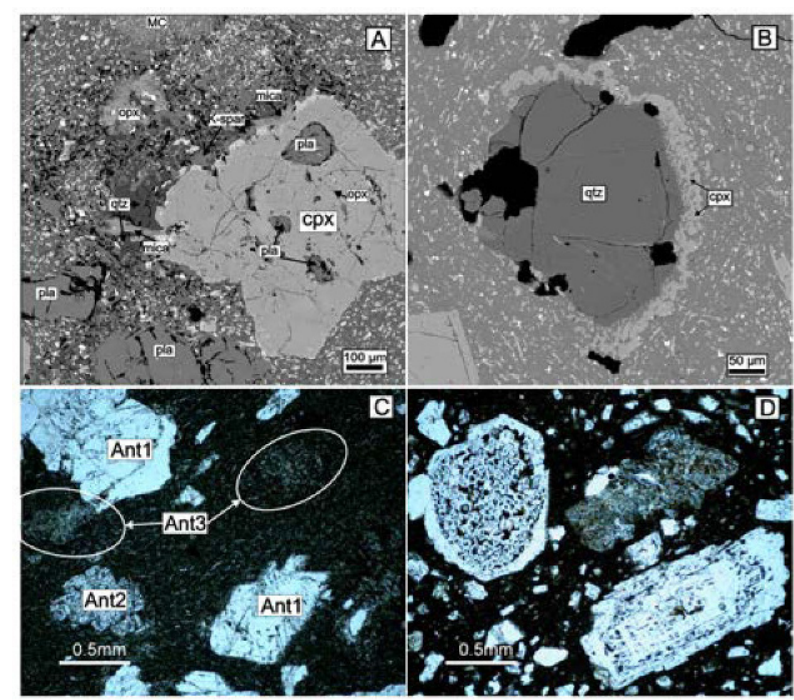

Figure 2. EDS images of some typical petrographic features of the Monte dei Porri lavas. A. A large clinopyroxene (cpx) antecryst with plagioclase (pla) and orthopyroxene (opx) inclusions surrounded by finer grained material. Finer-grained mica, K-feldspar (K-spar), quartz (qtz) and orthopyroxene (opx) are clustered within a zone adjacent to the cpx and may represent a glomerocryst. In the top centre of image a cluster of microcrystals (MC) interpreted to be a small crustal xenolith is present. B. Quartz antecryst partially surrounded by a clinopyroxene reaction rim. C. Image showing plagioclase feldspar antecrysts in sample SAL10 24 in various stages of resorption. Crystals labelled "Ant1" represent antecrysts that show little resorption, whereas the crystal labelled "Ant2" shows a much more advanced stage of resorption. White circles (Ant3) highlight antecrysts that have been almost completely resorbed and now show only a few microcrystalline "shadows". D. Plagioclase feldspar antecrysts from sample SAL10-21 showing zoning and dissolution/resorption textures in-filled with later crystalline material.

crystals that are finer grained than those in the other glomerocrysts but coarser than the groundmass of the lavas. The small size of the crystals in this final glomerocryst type made mineral identification difficult, but plagioclase and clinopyroxene were recognised. Rare xenocrysts of quartz rimmed by pyroxene (Figure $2 \mathrm{~B}$ ), or rimming and partially occupying vugs, were observed, but the quartz was not in equilibrium with the melt based on the observed textures. Disequilibrium "sieve" textures were common in plagioclase antecrysts, suggesting that they were in the process of being resorbed into the melt immediately before eruption [53] (Figure 2C). In addition, clusters of microplagioclase crystals which appear to be remnants of some larger plagioclase crystal that has been re-absorbed into the groundmass were observed (Figure 2D). Similar monomineralic clusters of micro-crystals have been identified in dacitic lavas of the Fossa delle Felci volcano, where they were described as "groundmass patches" [25, 26].
As previously discussed, the GPT consist of layers of scoria and pumice lapilli and indurated ashlapilli tuff. The mineral assemblage consists of calcic plagioclase+clinopyroxene+olivine+orthopyroxene+titanium-iron with accessory apatite (present as inclusions in antecryst phases). The pumices also contain amphibole. Rare mono- and multi-mineralic glomerocrysts were also observed in the GPT but single (isolated) crystals (antecrysts/phenocrysts) were more common. The olivine antecrysts in the GPT scoria unit are typically euhedral, with clear crystal boundaries surrounded by groundmass. However, olivine was also present in the rare GPT glomerocrysts as euhedral-subhedral crystals associated with clinopyroxene and plagioclase. Plagioclase antecrysts often contained vuggy cores which may be evidence that they were out of equilibrium with the melt at one point.

\subsection{Melt inclusions}

MI are ubiquitous in both the lava and GPT units. While the inclusions in the lava units are almost universally devitrified, $\mathrm{MI}$ in the GPT antecryst phases are typically glassy and contain one or more bubbles. The size, shape and degree of crystallisation of MI in the GPT vary depending on their host antecryst phase, but characteristics of $\mathrm{Ml}$ hosted in the same phase do not vary between the pumice and scoria beds [54].

As previously discussed, $\mathrm{MI}$ in plagioclase and pyroxene were not analysed as part of this study. In addition to the geochemical preference for analysing $\mathrm{MI}$ in primitive phases (olivine) discussed above, there were also practical considerations. While feldspar contains the greatest proportion of $\mathrm{Ml}$ overall (and most of these $\mathrm{Ml}$ are ovoid to negative crystal shaped), often these $\mathrm{MI}$ are within crystals that show a vuggy core, filled with interconnected anastomosing veins. This made identification and isolation of regularly-shaped inclusions difficult, as it required the polishing of crystal wafers to a thickness that would allow the transmission of light through these cores. However, this made the wafer too thin to mount in indium without fracturing the crystal. MI containing multiple bubbles were also common (Figure 3A). While these inclusions were typically larger than regularly-shaped inclusions, their mode of formation is unclear as they are not often aligned along growth surfaces. $\mathrm{Ml}$ in pyroxenes are not aligned parallel to growth surfaces but are still more common than $\mathrm{Ml}$ in olivine hosts. However, $\mathrm{Ml}$ in pyroxene almost universally contain daughter crystals (Figure 3B) and would require reheating and rehomogenisation before analysis.

$\mathrm{MI}$ are rare in olivine antecrysts from the GPT pumice units but are ubiquitous in olivines from the GPT scoria 


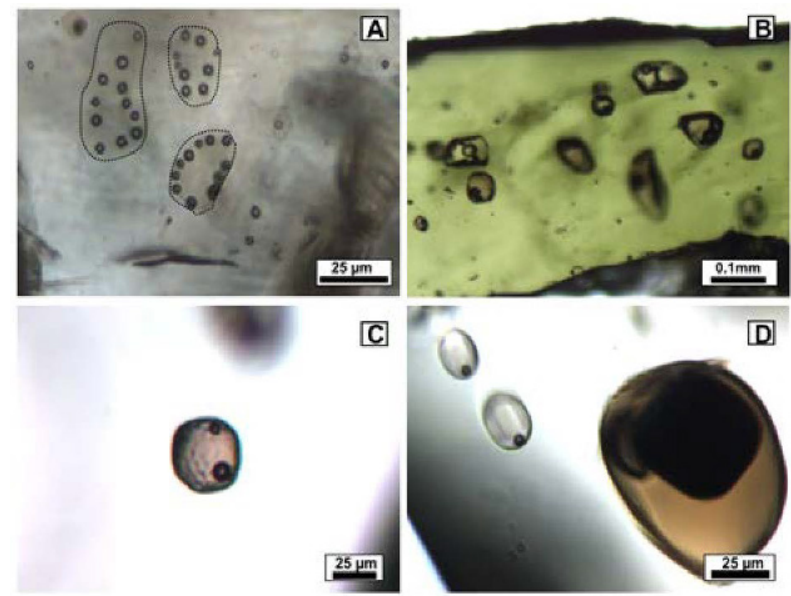

Figure 3. Selection of MI from GPT. A. Ml in feldspar host showing multiple bubbles (approximate outline of MI shown with a dotted line due to low contrast between $\mathrm{MI}$ and hos phase). B. MI containing multiple crystals in pyroxene host. C. MI in olivine showing characteristic "golf ball" negative crystal shape. D. Three MI in olivine, with the large $\mathrm{Ml}$ on the right containing an entrapped oxide mineral.

units. The morphologies of the Ml are typically rounded, but negative crystal shapes also occur, some showing a distinctive "golf ball" texture (Figure 3C). The Ml range in size from $\sim 2-35 \mu \mathrm{m}$ in diameter, but some rare inclusions up to $150 \mu \mathrm{m}$ were observed. The larger inclusions are typically more irregularly-shaped and often contain more than one bubble. In both units, $\mathrm{Ml}$ are typically glassy with one or more bubbles and are often associated with entrapped Ti-Fe oxide crystals (based on the random crystal size and distribution) in the scoria units (Figure 3D). However, partially or totally recrystallised $\mathrm{Ml}$ are also found in the olivines of the pumice unit, and often glassy and recrystallised inclusions can be found in the same antecryst.

$\mathrm{Ml}$ with a single bubble show a constant $\mathrm{V}_{\text {melt }} / \mathrm{V}_{\text {bubble }}$ regardless of the Ml size in both the pumice and the scoria units of the GPT.

\section{Geochemistry}

The products of Monte dei Porri range from basalt to andesite and straddle the calc-alkaline - high- $\mathrm{K}$ calcalkaline affinity boundary (Figures 4 and 5). The compositions of Monte dei Porri eruptive products overlap the trend of the other western Aeolian arc volcanoes. The Monte dei Porri lavas have bulk rock $\mathrm{SiO}_{2}$ contents of 53.1-56 wt \% and total alkali contents of 4.3-4.9 wt \% (Table 1). These values plot in the basaltic-andesite field and

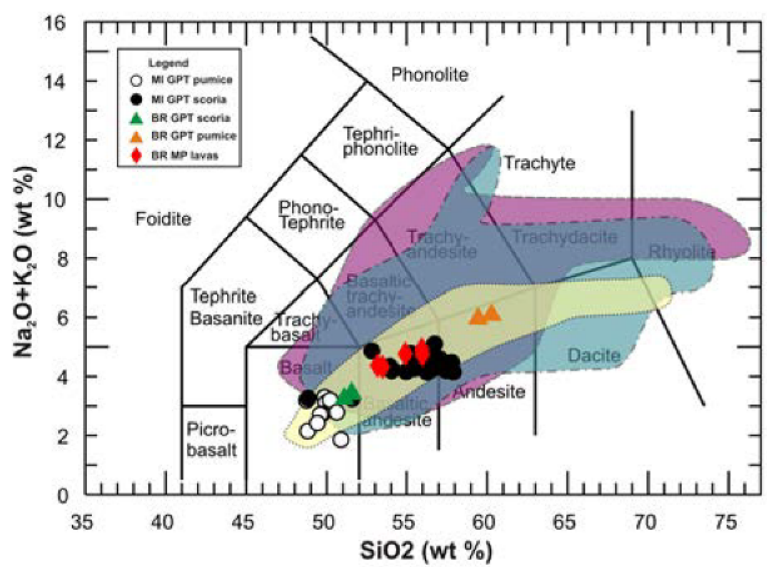

Figure 4. TAS diagram showing bulk rock compositions of Monte dei Porri products and compositions of melt inclusions from the GPT. Fields show bulk rock compositions for the other Aeolian Islands using the classification described by Peccerillo [23] (and references therein), purple representing the central arc (Lipari and Vulcano), blue representing the eastern arc (Panarea and Stromboli) and yellow representing the western arc (Alicudi, Filicudi and Salina).

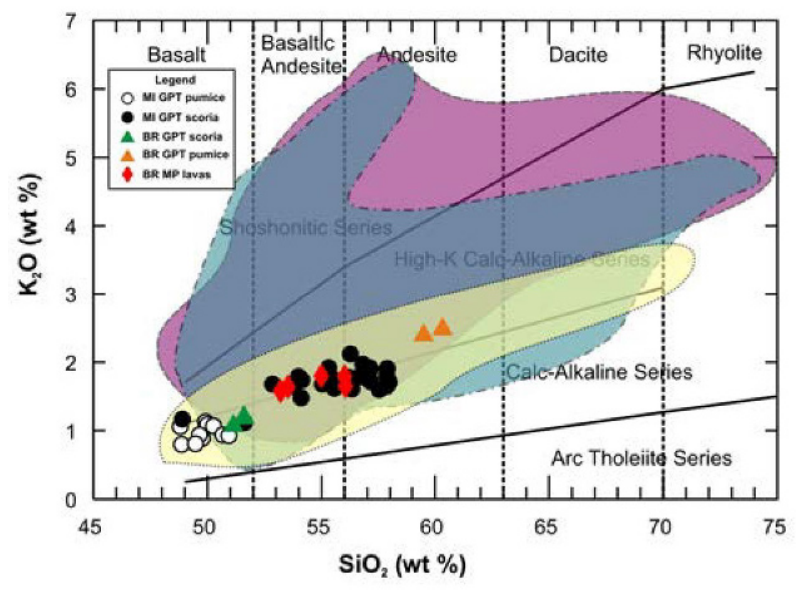

Figure 5. $\mathrm{K}_{2} \mathrm{O}$ versus $\mathrm{SiO}_{2}$ discrimination diagram for the Monte dei Porri products based on the model of Peccerillo and Taylor [59]. Note: MP = Monte dei Porri; BR = Bulk Rock compositions. Fields are the same as Figure 4.

agree with the few geochemical data published on Monte dei Porri (Figure 4).

The MI in GPT scoriae have compositions similar to the lavas with $\mathrm{SiO}_{2}$ contents of 48.8-57.9 wt \% and total alkali contents of between 4-5 wt \%. The Ml compositions of the GPT pumice unit range from 51.1-51.5 wt \% and 3.2$3.4 \mathrm{wt} \%$ total alkali, which correspond to the high-silica basalt field, making them more primitive in composition than MI of the GPT scoria units and more primitive than 
Table 1. Major and trace element data for bulk rock samples. Major elements (including first Ba value) were analysed using XRF and values are presented in wt\%, trace elements were analysed using ICP-MS and values are in ppm with the exception of Au which is presented in ppb.

\begin{tabular}{|c|c|c|c|c|c|c|c|c|c|c|}
\hline \multirow{2}{*}{\multicolumn{6}{|c|}{ Monte dei Porri lavas }} & \multicolumn{5}{|c|}{ Grey Porri Tuff (GPT) } \\
\hline & & & & & & \multicolumn{3}{|c|}{ Pumices } & \multicolumn{2}{|c|}{ Scoria } \\
\hline & SAL10-21 & SAL10-22 & SAL10-24 & SAL10-26 & SAL10-27 & SAL10-11A & SAL10-11B & SAL10-4A & SAL10-4B & SAL10-4C \\
\hline $\mathrm{SiO}_{2}$ & 53.3 & 53.8 & 55.8 & 55.9 & 54.8 & 60.8 & 59.9 & 51.9 & 51.5 & 51.1 \\
\hline $\mathrm{Al}_{2} \mathrm{O}_{3}$ & 17.63 & 18.72 & 17.59 & 17.58 & 18.63 & 16.73 & 16.69 & 18.74 & 18.16 & 19.49 \\
\hline $\mathrm{Fe}_{2} \mathrm{O}_{3}$ & 9.93 & 8.97 & 8.61 & 8.89 & 8.63 & 5.78 & 6.08 & 9.69 & 9.47 & 9.19 \\
\hline $\mathrm{CaO}$ & 9.18 & 9.28 & 7.99 & 7.97 & 8.66 & 5.81 & 5.93 & 9.02 & 9.63 & 8.49 \\
\hline $\mathrm{MgO}$ & 4.41 & 3.81 & 3.26 & 3.48 & 3.07 & 2.42 & 2.54 & 4.29 & 4.6 & 3.2 \\
\hline $\mathrm{Na}_{2} \mathrm{O}$ & 2.79 & 2.69 & 3.1 & 3.08 & 2.94 & 3.62 & 3.58 & 2.24 & 2.21 & 2.16 \\
\hline $\mathrm{K}_{2} \mathrm{O}$ & 1.59 & 1.66 & 1.8 & 1.66 & 1.81 & 2.51 & 2.42 & 1.2 & 1.21 & 1.08 \\
\hline $\mathrm{MnO}$ & 0.18 & 0.16 & 0.16 & 0.17 & 0.16 & 0.16 & 0.16 & 0.17 & 0.17 & 0.17 \\
\hline $\mathrm{TiO}_{2}$ & 0.74 & 0.71 & 0.74 & 0.78 & 0.73 & 0.54 & 0.54 & 0.73 & 0.71 & 0.7 \\
\hline $\mathrm{P}_{2} \mathrm{O}_{5}$ & 0.2 & 0.2 & 0.21 & 0.2 & 0.21 & 0.16 & 0.15 & 0.14 & 0.14 & 0.14 \\
\hline $\mathrm{Ba}$ & 0.04 & 0.05 & 0.04 & 0.04 & 0.05 & 0.06 & 0.06 & 0.04 & 0.04 & 0.05 \\
\hline LOI & 0.29 & 0.57 & 0.44 & 0.09 & 0.08 & 2.27 & 2.71 & 2.54 & 2.09 & 4.26 \\
\hline Total & 100.31 & 100.63 & 99.76 & 99.81 & 99.81 & 100.91 & 100.72 & 100.68 & 99.92 & 100.07 \\
\hline $\mathrm{Ba}$ & 436 & 486 & 464 & 446 & 487 & 685 & 679 & 434 & 419 & 508 \\
\hline $\mathrm{Be}$ & $<1$ & 2 & 2 & $<1$ & $<1$ & 2 & 2 & $<1$ & 1 & 2 \\
\hline Co & 27.7 & 26 & 19.4 & 21.4 & 20.9 & 13.7 & 14.2 & 27.2 & 26.3 & 24.6 \\
\hline Cs & 1.3 & 1.2 & 1.4 & 1.4 & 0.6 & 2 & 2.2 & 1.2 & 1.2 & 1.1 \\
\hline Ga & 19.4 & 17.3 & 18.4 & 18.7 & 20.1 & 18.7 & 16.8 & 17.7 & 17.2 & 20.9 \\
\hline $\mathrm{Hf}$ & 2 & 2 & 2.2 & 2.5 & 2.5 & 2.6 & 2.8 & 1.5 & 1.8 & 2.1 \\
\hline $\mathrm{Nb}$ & 4.9 & 4.7 & 5.6 & 5.5 & 5.3 & 8.6 & 8.2 & 4.8 & 4.7 & 4.8 \\
\hline $\mathrm{Rb}$ & 37.4 & 38.9 & 43 & 41 & 39.6 & 67 & 65.9 & 33.2 & 31.8 & 38.1 \\
\hline Sn & 1 & $<1$ & 1 & 1 & $<1$ & $<1$ & 1 & $<1$ & $\mid<1$ & $<1$ \\
\hline $\mathrm{Sr}$ & 792.1 & 842.4 & 738.5 & 712.8 & 792.4 & 711.6 & 701.7 & 766.4 & 776.6 & 846.6 \\
\hline $\mathrm{Ta}$ & 0.2 & 0.2 & 0.4 & 0.3 & 0.3 & 0.4 & 0.5 & 0.2 & 0.3 & 0.2 \\
\hline Th & 5.7 & 5.8 & 5 & 4.9 & 5 & 9.2 & 8.5 & 4.5 & 4.4 & 5 \\
\hline U & 1.5 & 1.5 & 1.7 & 1.6 & 1.7 & 2.9 & 2.8 & 1.3 & 1.2 & 1.5 \\
\hline V & 347 & 296 & 254 & 269 & 267 & 142 & 146 & 269 & 302 & 200 \\
\hline W & 0.7 & $<0.5$ & 0.7 & 0.5 & 1 & 1.1 & 1.1 & 0.6 & $<0.5$ & $<0.5$ \\
\hline $\mathrm{Zr}$ & 67.5 & 64.5 & 74 & 75.9 & 69.6 & 108.9 & 105.2 & 64.6 & 63.4 & 65.9 \\
\hline Y & 18.9 & 18.4 & 21.2 & 21 & 19.4 & 20.6 & 20.7 & 16.9 & 16.6 & 19.4 \\
\hline La & 18.2 & 20.2 & 20.1 & 19.2 & 20.7 & 30.6 & 30.1 & 18.4 & 17.7 & 20.1 \\
\hline $\mathrm{Ce}$ & 35.6 & 37.7 & 39.3 & 37.2 & 39.5 & 54.3 & 52.7 & 38.1 & 34.7 & 37.8 \\
\hline $\operatorname{Pr}$ & 4.46 & 4.79 & 4.81 & 4.6 & 4.82 & 6.41 & 6.31 & 4.34 & 4.11 & 4.73 \\
\hline $\mathrm{Nd}$ & 17.2 & 18.8 & 19.3 & 18.5 & 20.1 & 24.2 & 22.7 & 17.2 & 15.7 & 19.6 \\
\hline $\mathrm{Sm}$ & 3.57 & 3.67 & 4.11 & 3.97 & 4.04 & 4.59 & 4.51 & 3.74 & 3.52 & 3.81 \\
\hline Eu & 1.16 & 1.19 & 1.24 & 1.22 & 1.27 & 1.23 & 1.24 & 1.1 & 1.05 & 1.25 \\
\hline Gd & 3.58 & 3.36 & 3.85 & 3.81 & 3.92 & 3.77 & 3.84 & 3.32 & 3.27 & 3.67 \\
\hline Tb & 0.57 & 0.55 & 0.63 & 0.62 & 0.6 & 0.61 & 0.61 & 0.55 & 0.51 & 0.57 \\
\hline Dy & 3.14 & 3.01 & 3.86 & 3.77 & 3.35 & 3.49 & 3.48 & 3.13 & 3.13 & 3.17 \\
\hline Ho & 0.67 & 0.65 & 0.8 & 0.76 & 0.71 & 0.74 & 0.75 & 0.62 & 0.62 & 0.68 \\
\hline $\mathrm{Er}$ & 1.88 & 1.88 & 2.29 & 2.28 & 2 & 2.17 & 2.21 & 1.66 & 1.72 & 1.94 \\
\hline $\mathrm{Tm}$ & 0.29 & 0.29 & 0.35 & 0.34 & 0.34 & 0.33 & 0.34 & 0.27 & 0.27 & 0.29 \\
\hline$Y b$ & 1.8 & 1.85 & 2.14 & 2.18 & 2.02 & 2.17 & 2.37 & 1.7 & 1.79 & 1.96 \\
\hline Lu & 0.3 & 0.29 & 0.35 & 0.36 & 0.32 & 0.38 & 0.37 & 0.28 & 0.27 & 0.31 \\
\hline Mo & 0.6 & 0.5 & 0.5 & 0.2 & 0.9 & 0.3 & 0.3 & $<0.1$ & 0.1 & $<0.1$ \\
\hline $\mathrm{Cu}$ & 54.5 & 44.6 & 52.7 & 32.7 & 92.4 & 19 & 29.1 & 40.1 & 40.3 & 102.8 \\
\hline $\mathrm{Pb}$ & 3.5 & 2 & 0.8 & 0.4 & 3.3 & 0.7 & 0.9 & 2 & 1.6 & 2.8 \\
\hline $\mathrm{Zn}$ & 29 & 33 & 25 & 20 & 45 & 13 & 15 & 25 & 23 & 39 \\
\hline $\mathrm{Ni}$ & 5.5 & 6.8 & 1.9 & 2 & 3.5 & 4.1 & 4.8 & 10 & 9.9 & 7 \\
\hline As & $<0.5$ & $<0.5$ & $<0.5$ & $<0.5$ & 0.9 & 0.6 & $<0.5$ & $<0.5$ & 0.7 & 0.7 \\
\hline $\mathrm{Cd}$ & $<0.1$ & $<0.1$ & $<0.1$ & $<0.1$ & $<0.1$ & $<0.1$ & $<0.1$ & $<0.1$ & $<0.1$ & $<0.1$ \\
\hline $\mathrm{Sb}$ & $<0.1$ & $<0.1$ & $<0.1$ & $<0.1$ & $<0.1$ & $<0.1$ & $<0.1$ & $<0.1$ & $\mid<0.1$ & $<0.1$ \\
\hline $\mathrm{Bi}$ & $<0.1$ & $<0.1$ & $<0.1$ & $<0.1$ & $<0.1$ & $<0.1$ & $<0.1$ & $<0.1$ & $\mid<0.1$ & $<0.1$ \\
\hline $\mathrm{Ag}$ & $<0.1$ & $<0.1$ & $<0.1$ & $<0.1$ & $<0.1$ & $<0.1$ & $<0.1$ & $<0.1$ & $<0.1$ & $<0.1$ \\
\hline $\mathrm{Au}$ & 1.6 & $<0.5$ & $<0.5$ & $<0.5$ & $<0.5$ & $\mid 1.1$ & 2.8 & $<0.5$ & 1.5 & 1.9 \\
\hline $\mathrm{Hg}$ & 0.01 & $<0.01$ & $<0.01$ & $<0.01$ & $<0.01$ & $<0.01$ & $<0.01$ & $<0.01$ & $<0.01$ & $<0.01$ \\
\hline $\mathrm{Tl}$ & $<0.1$ & $<0.1$ & $<0.1$ & $<0.1$ & $<0.1$ & $<0.1$ & $<0.1$ & $<0.1$ & $<0.1$ & $<0.1$ \\
\hline Se & $<0.5$ & $<0.5$ & $<0.5$ & $<0.5$ & $<0.5$ & $<0.5$ & $<0.5$ & $<0.5$ & $<0.5$ & $<0.5$ \\
\hline
\end{tabular}




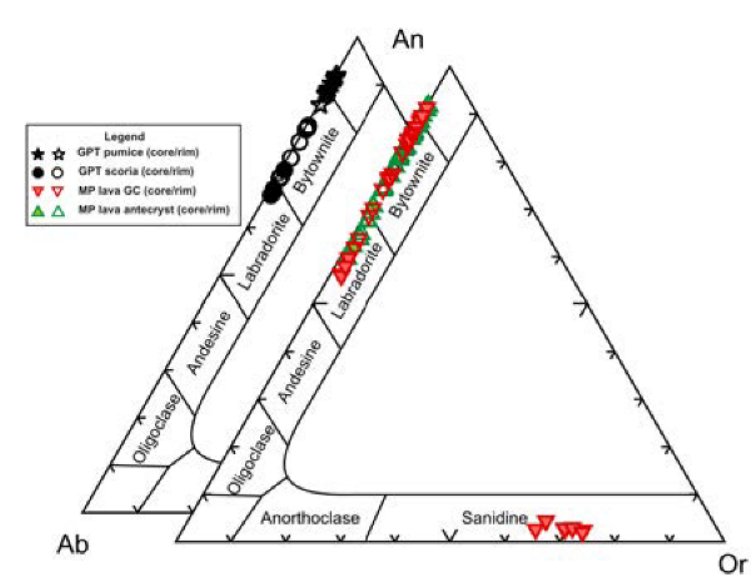

Figure 6. Ternary feldspar diagrams showing compositions of antecrysts from the GPT pumices, GPT scoriae, Monte dei Porri lava antecrysts and Monte dei Porri glomerocrysts (GC).

the bulk-rock compositions of both the GPT and Monte dei Porri lava units.

The pumices show a larger difference in composition between bulk rock and $\mathrm{Ml}$ compared to the lavas. The 2 horizons in the GPT pumice unit have bulk rock $\mathrm{SiO}_{2}$ contents of 58.4 and 57.9 wt \% and total alkali contents of 6.0 and $6.1 \mathrm{wt} \%$. These values plot in the high-alkali end of the andesite field. However, MI in the GPT pumice unit have more mafic compositions of 47.1-50.3 wt \% $\mathrm{SiO}_{2}$ and 1.8-3.2 wt \% total alkali and plot in the basalt field.

\subsection{Mineral chemistry}

The compositions of the major mineral phases differ between different units. Olivine was the major host phase for $\mathrm{Ml}$ used in this study and its composition is discussed in more detail. The compositions of the pyroxene and plagioclase phases are described only briefly below and representative compositions are presented in Table 2, along with representative olivine compositions.

Feldspars in the Monte dei Porri lavas vary from labradorite to anorthite and the lava units contain a small amount of sanidine, which is absent in the GPT. In the GPT, feldspars show a bimodal distribution with those in the GPT pumice unit having a distinctly more calcic composition compared to feldspars in GPT scoria unit. Feldspar shows both oscillatory and normal zoning in the Monte de Porri lava units and the GPT. The GPT also contains unzoned feldspar crystals. The compositions of feldspars in glomerocrysts of the Monte dei Porri lava units overlap with compositions of the antecrysts in the host-lavas and the GPT scoria unit (Figure 6).

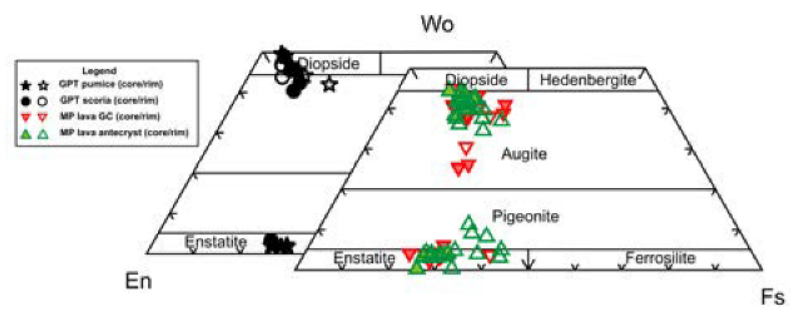

Figure 7. Ternary wollastonite (Wo) - enstatite (En) - ferrosilite (Fs) pyroxene diagram showing compositions of antecrysts from the Monte dei Porri products as in Figure 6.

Both orthopyroxene and clinopyroxene are found in the Monte dei Porri lava units and the GPT. In general, clinopyroxene antecrysts in the lava units show lessevolved augite compositions compared to the clinopyroxene in the GPT, which have more evolved augite and diopside compositions. Cores of pyroxenes in the GPT pumice unit are more evolved compared to the rims, but this trend is reversed in GPT scoria-hosted pyroxenes (Figure 7). As with feldspar, the compositions of the clinopyroxene antecrysts hosted in glomerocrysts in the Monte dei Porri lava units overlap with the compositions of clinopyroxene antecrysts in the host-lavas.

The Monte dei Porri lavas contain a mixture of both normally zoned and homogeneous (unzoned) olivine antecrysts (Figure 8). Individual olivine antecrysts that are surrounded by groundmass show normal zoning and large variations in $\mathrm{F}_{0}$, ranging from $\mathrm{F}_{56-74}$ at the rim (average of $\mathrm{Fo}_{66}$ ), and $\mathrm{Fo}_{65-78}$ at the cores (average of $\mathrm{F}_{\mathrm{O}_{72}}$ ). Within individual antecrysts the Fo content from core to rim differed by as little as 0.75 to as much as $14.35 \mathrm{~mol} \%$. However, olivines that were part of glomerocrysts were typically unzoned, with rim compositions ranging from $\mathrm{Fo}_{58-70}$ and core compositions of $\mathrm{F}_{\mathrm{O}_{67-72}}$.

Olivine from the GPT are typically homogeneous in composition and fall within a narrow range. Olivine antecrysts in the GPT scoria units are $\mathrm{F}_{072}-79$, with an average of $\mathrm{F}_{073}$. Olivine antecrysts in the GPT pumice units are more mafic with $\mathrm{F}_{0_{81-84}}$, with an average of $\mathrm{Fo}_{82}$ (Table 2 \& 3). Traverses across olivine antecrysts that contain $\mathrm{MI}$ revealed a 0.5 to $2 \%$ range in Fo-content with a maximum variation in Fo content of $7 \%$ in one crystal - the host of $\mathrm{Ml}$ 4bolv01-i1. This larger difference is anomalous as other olivine antecrysts in this unit (SAL10-4B) show an average variation in Fo content of less than 1\% from core to rim.

\subsection{Melt inclusion chemistry}

While $\mathrm{Ml}$ provide valuable information on the composition of the melt at the time of $\mathrm{Ml}$ entrapment, care must 


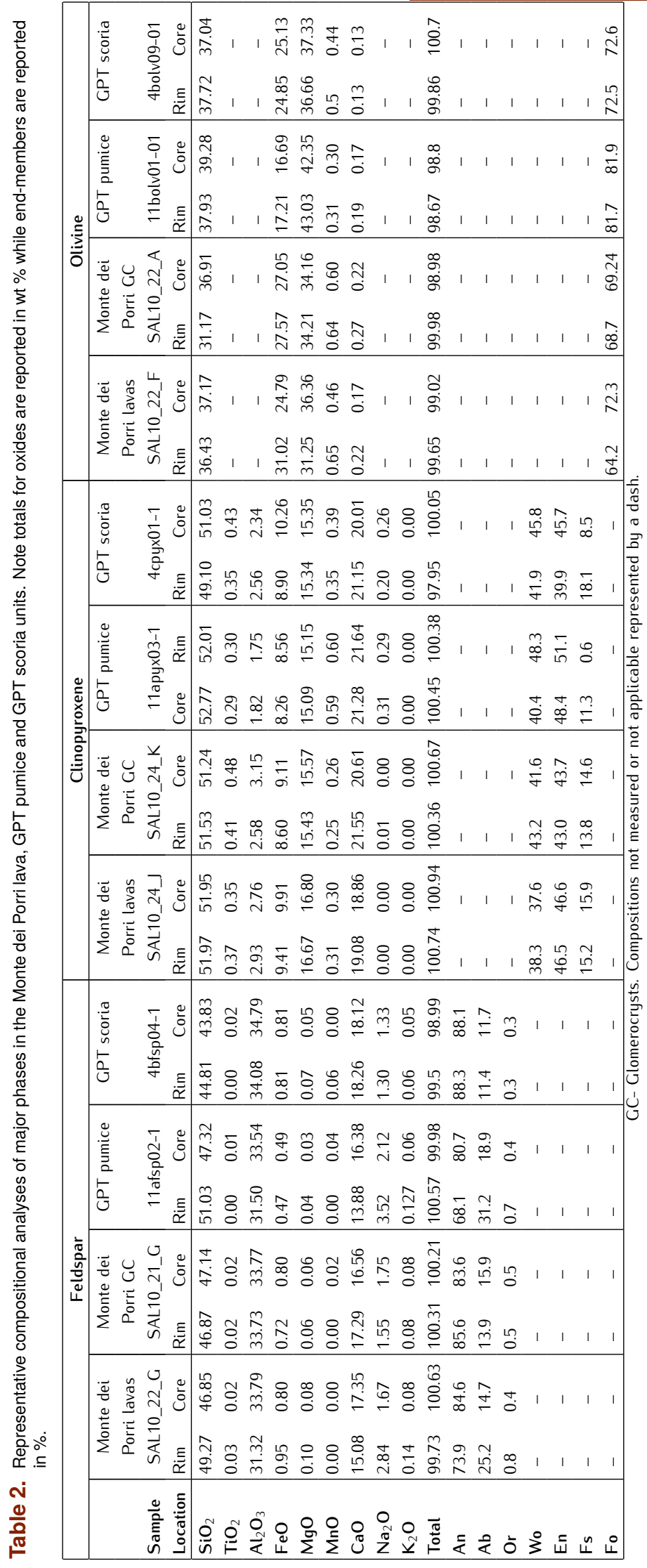


Table 3. Geochemistry of melt inclusions of GPT corrected for post entrapment crystallisation. Major element abundances have been normalised to $100 \%$ and are presented in wt \%.

\begin{tabular}{|c|c|c|c|c|c|c|c|c|c|c|c|c|c|c|c|c|}
\hline & Sample & $\mathrm{SiO}_{2}$ & $\mathrm{TiO}_{2}$ & $\mathrm{Al}_{2} \mathrm{O}_{3}$ & $\mathrm{Fe}_{2} \mathrm{O}_{3}$ & $\mathrm{FeO}$ & $\mathrm{MnO}$ & $\mathrm{MgO}$ & $\mathrm{CaO}$ & $\mathrm{Na}_{2} \mathrm{O}$ & $\mathrm{K}_{2} \mathrm{O}$ & $\mathbf{P}_{2} \mathbf{O}_{5}$ & $\mathrm{Cr}_{2} \mathrm{O}_{3}$ & $\begin{array}{l}\text { Olv } \\
\text { cryst. }\end{array}$ & $\mathrm{Mg} \#$ & $\begin{array}{l}\text { Host } \\
\text { Olv } \mathrm{F}_{0} \%\end{array}$ \\
\hline \multirow{29}{*}{ 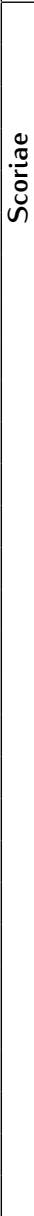 } & 4aolv02-i1 & 56.04 & 0.85 & 16.12 & 2.87 & 7.20 & 0.23 & 3.80 & 8.13 & 2.73 & 1.70 & 0.28 & 0.06 & 0.65 & 48 & 72.5 \\
\hline & 4aolv02-i2 & 55.55 & 0.89 & 16.04 & 3.07 & 7.33 & 0.15 & 3.86 & 8.33 & 2.76 & 1.72 & 0.25 & 0.03 & 1.98 & 48 & 72.5 \\
\hline & 4aolv03-i1 & 56.13 & 0.84 & 15.95 & 3.01 & 7.15 & 0.17 & 3.73 & 8.03 & 2.95 & 1.79 & 0.20 & 0.03 & 0.89 & 48 & 72.5 \\
\hline & 4aolv03-i2 & 56.21 & 0.97 & 15.83 & 3.04 & 7.04 & 0.22 & 3.67 & 7.87 & 2.74 & 2.13 & 0.27 & 0.00 & 2.49 & 48 & 72.5 \\
\hline & 4aolv03-i4 & 52.80 & 0.90 & 18.38 & 2.97 & 6.83 & 0.22 & 3.48 & 9.40 & 3.17 & 1.69 & 0.17 & 0.00 & 0.42 & 48 & 72.5 \\
\hline & 4aolv04-5 & 57.80 & 0.80 & 14.64 & 2.93 & 7.25 & 0.19 & 3.91 & 7.68 & 2.67 & 1.81 & 0.31 & 0.01 & 0.00 & 49 & 72.5 \\
\hline & 4aolv04-i1 & 57.80 & 0.79 & 15.73 & 2.66 & 7.20 & 0.22 & 3.82 & 7.27 & 2.57 & 1.66 & 0.28 & 0.01 & 0.63 & 49 & 72.5 \\
\hline & 4aolv04-i2 & 57.91 & 0.77 & 15.11 & 2.76 & 7.35 & 0.16 & 3.95 & 7.50 & 2.43 & 1.72 & 0.27 & 0.06 & 1.87 & 49 & 72.5 \\
\hline & 4aolv04-i3 & 57.47 & 0.83 & 15.80 & 2.61 & 7.10 & 0.21 & 3.78 & 7.75 & 2.58 & 1.61 & 0.25 & 0.00 & 0.00 & 49 & 72.5 \\
\hline & 4aolv04-i4 & 57.08 & 0.81 & 15.60 & 2.69 & 7.06 & 0.29 & 3.93 & 7.85 & 2.64 & 1.73 & 0.30 & 0.03 & 0.00 & 50 & 72.5 \\
\hline & 4aolv05-i2 & 54.05 & 0.83 & 17.08 & 2.79 & 7.25 & 0.24 & 4.16 & 9.15 & 2.69 & 1.49 & 0.26 & 0.02 & 0.00 & 51 & 72.7 \\
\hline & 4aolv07-i1 & 55.50 & 0.83 & 15.67 & 3.17 & 7.62 & 0.21 & 4.07 & 8.33 & 2.63 & 1.63 & 0.33 & 0.00 & 4.08 & 49 & 72.5 \\
\hline & 4bolv01-i1 & 51.57 & 0.86 & 18.48 & 2.55 & 7.41 & 0.21 & 4.21 & 11.26 & 2.11 & 1.13 & 0.19 & 0.03 & 0.00 & 50 & 72.5 \\
\hline & 4bolv02-i1 & 48.84 & 0.86 & 19.40 & 2.79 & 7.84 & 0.20 & 5.47 & 11.12 & 2.08 & 1.18 & 0.21 & 0.00 & 2.63 & 55 & 78.5 \\
\hline & 4colv01-i1 & 55.26 & 0.84 & 16.26 & 3.26 & 7.37 & 0.29 & 3.77 & 7.83 & 2.85 & 1.93 & 0.33 & 0.00 & 3.58 & 48 & 72.0 \\
\hline & 4 colv01-i2 & 54.08 & 0.82 & 16.86 & 3.51 & 8.12 & 0.18 & 4.21 & 7.68 & 2.51 & 1.75 & 0.22 & 0.07 & 8.28 & 48 & 72.0 \\
\hline & 4colv01-i3 & 53.93 & 0.81 & 17.22 & 3.41 & 7.95 & 0.23 & 4.10 & 7.78 & 2.55 & 1.80 & 0.24 & 0.00 & 7.08 & 48 & 72.0 \\
\hline & 4colv03-i3 & 54.98 & 0.86 & 15.97 & 3.53 & 8.14 & 0.14 & 4.21 & 7.72 & 2.47 & 1.69 & 0.29 & 0.02 & 8.64 & 48 & 72.0 \\
\hline & 4colv04-i1 & 55.84 & 0.81 & 17.13 & 2.70 & 7.13 & 0.20 & 3.60 & 7.95 & 2.67 & 1.70 & 0.26 & 0.02 & 0.01 & 47 & 71.7 \\
\hline & 4 colv04-i2 & 57.08 & 0.83 & 16.41 & 2.75 & 7.07 & 0.19 & 3.55 & 7.27 & 2.68 & 1.91 & 0.25 & 0.01 & 0.56 & 47 & 71.7 \\
\hline & 4 colv04-i3 & 55.41 & 0.81 & 17.12 & 2.85 & 7.18 & 0.25 & 3.62 & 7.96 & 2.75 & 1.77 & 0.27 & 0.00 & 0.85 & 47 & 71.7 \\
\hline & 4colv05-i1 & 56.27 & 0.85 & 15.85 & 2.92 & 7.48 & 0.32 & 3.91 & 8.00 & 2.52 & 1.62 & 0.27 & 0.00 & 3.38 & 48 & 72.0 \\
\hline & 4colv05-i2 & 56.22 & 0.79 & 15.91 & 3.14 & 7.78 & 0.20 & 4.06 & 7.52 & 2.50 & 1.72 & 0.16 & 0.00 & 6.23 & 48 & 72.0 \\
\hline & 4colv06-i1 & 56.29 & 0.85 & 15.90 & 3.08 & 7.63 & 0.18 & 3.97 & 7.57 & 2.50 & 1.77 & 0.25 & 0.02 & 4.91 & 48 & 72.0 \\
\hline & 4 colv06-i2 & 57.82 & 0.81 & 14.90 & 3.19 & 7.86 & 0.19 & 4.13 & 6.61 & 2.30 & 1.92 & 0.27 & 0.00 & 6.84 & 48 & 72.0 \\
\hline & 4colv06-i3 & 57.05 & 0.87 & 15.86 & 3.02 & 7.41 & 0.20 & 3.81 & 6.91 & 2.60 & 1.93 & 0.29 & 0.06 & 4.40 & 48 & 72.0 \\
\hline & 4colv10-i1 & 56.61 & 0.87 & 15.65 & 3.09 & 7.64 & 0.25 & 3.93 & 7.45 & 2.45 & 1.80 & 0.24 & 0.01 & 4.37 & 48 & 71.7 \\
\hline & $4 \operatorname{colv} 10-\mathrm{i} 2$ & 56.75 & 0.80 & 15.81 & 2.84 & 6.71 & 0.18 & 3.35 & 8.09 & 3.12 & 1.98 & 0.36 & 0.02 & 0.21 & 47 & 71.7 \\
\hline & 4colv12-i1 & 53.70 & 0.93 & 17.04 & 3.18 & 7.46 & 0.19 & 3.79 & 9.03 & 2.64 & 1.66 & 0.36 & 0.00 & 3.04 & 48 & 71.7 \\
\hline \multirow{10}{*}{ 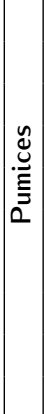 } & 11aolv05-i1 & 49.86 & 0.70 & 19.91 & 2.56 & 6.24 & 0.09 & 4.92 & 12.22 & 2.16 & 1.14 & 0.22 & 0.00 & 6.76 & 58 & 80.5 \\
\hline & 11aolv05-i2 & 50.21 & 0.76 & 19.69 & 2.55 & 6.28 & 0.15 & 4.97 & 12.03 & 2.12 & 1.08 & 0.11 & 0.05 & 7.02 & 59 & 80.5 \\
\hline & 11 aolv05-i3 & 49.94 & 0.73 & 19.86 & 2.59 & 6.43 & 0.07 & 5.09 & 12.07 & 2.00 & 1.10 & 0.11 & 0.00 & 7.83 & 59 & 80.5 \\
\hline & 11bolv01-i1 & 49.72 & 0.64 & 19.07 & 2.78 & 6.87 & 0.11 & 5.91 & 12.03 & 1.83 & 0.90 & 0.13 & 0.01 & 10.47 & 61 & 81.7 \\
\hline & 11bolv01-i2 & 48.81 & 0.66 & 18.31 & 3.26 & 7.73 & 0.14 & 6.76 & 12.03 & 1.34 & 0.81 & 0.12 & 0.03 & 15.27 & 61 & 81.7 \\
\hline & 11bolv01-i3 & 49.59 & 0.67 & 18.70 & 3.02 & 7.12 & 0.11 & 6.15 & 11.76 & 1.76 & 0.95 & 0.14 & 0.04 & 12.91 & 61 & 81.7 \\
\hline & 11bolv02-i1 & 49.42 & 0.96 & 18.48 & 3.20 & 7.41 & 0.17 & 6.58 & 11.20 & 1.60 & 0.82 & 0.17 & 0.00 & 14.82 & 61 & 82.0 \\
\hline & 11bolv03-i1 & 48.75 & 0.74 & 19.16 & 2.75 & 6.33 & 0.19 & 5.76 & 12.96 & 2.12 & 1.07 & 0.17 & 0.00 & 7.70 & 62 & 83.5 \\
\hline & 11 bolv05-i1 & 50.62 & 0.66 & 18.69 & 2.61 & 6.64 & 0.12 & 5.68 & 12.04 & 1.83 & 0.95 & 0.15 & 0.02 & 9.75 & 60 & 81.5 \\
\hline & 11bolv08-i1 & 50.88 & 0.75 & 18.16 & 2.40 & 6.99 & 0.15 & 6.14 & 12.49 & 0.92 & 0.94 & 0.17 & 0.01 & 9.67 & 61 & 81.5 \\
\hline
\end{tabular}

Olv crst $=$ percentage of olivine crystallised on the wall after trapping; $\mathrm{Mg} \#=((\mathrm{MgO} * 40.3) /((\mathrm{MgO} * 40.3)+(\mathrm{FeO} * 71.85)) * 100 ; \mathrm{Host} \mathrm{Olv}$. $F_{0 .}=$ forsterite in mol\% of olivine host.

be taken in the interpretation of $\mathrm{Ml}$ data to confirm $\mathrm{MI}$ compositions have not been modified by post-entrapment processes [7].

\subsubsection{Post-entrapment modification of melt inclusions}

Kent [7] (and references therein) reported that $\mathrm{Ml}$ that had undergone Fe-loss through element diffusion could be identified based on the fact that their compositions would 


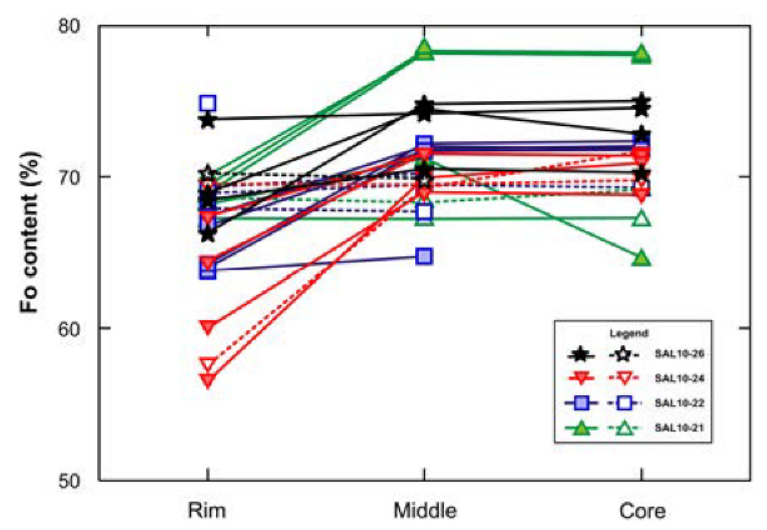

Figure 8. Forsterite (Fo) compositional profiles of olivine from the Monte dei Porri lavas. Note the filled symbols with solid lines represent crystals surrounded by groundmass and the outlined symbols with dashed lines represent crystals from glomerocrysts.

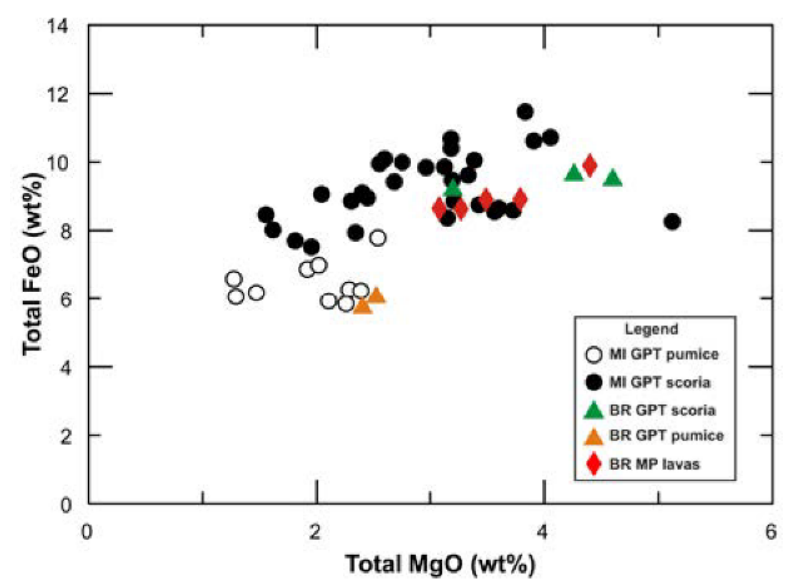

Figure 9. Total FeO vs. MgO for uncorrected melt inclusion compositions and bulk rock compositions for the GPT and Monte dei Porri lavas.

fall below the liquid line of descent predicted from bulk rock and matrix glass compositions of their host rocks. A plot of $\mathrm{FeO}$ (Total) vs. $\mathrm{MgO}$ of uncorrected compositions of $\mathrm{MI}$ in olivine shows that $\mathrm{FeO}$ contents are similar to, or higher than, the $\mathrm{FeO}$ content of the bulk rock composition (Figure 9), indicating that the inclusions have not experienced Fe loss through element diffusion. For this reason, no iron-loss correction was made to the $\mathrm{Ml}$ compositions.

A test using the Petrolog3 program [55] indicated that post-entrapment crystallisation of olivine on the walls of the inclusions occurred after entrapment. Therefore, the inclusion compositions were corrected for post entrapment crystallisation using the "Olivine MI" function of the Petrolog3 program, following the method described

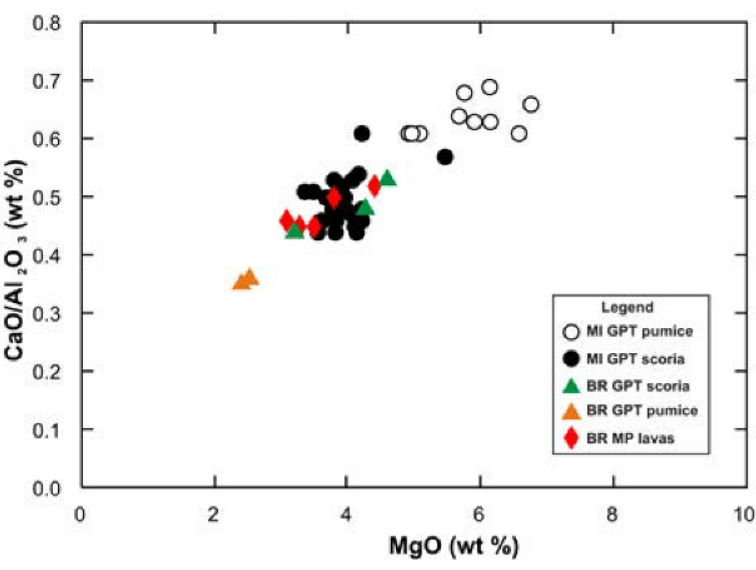

Figure 10. Relationship between $\mathrm{CaO} / \mathrm{Al}_{2} \mathrm{O}_{3}$ and $\mathrm{MgO}$ contents of $\mathrm{MI}$ and bulk rock compositions of GPT products.

by Danyushevsky [55]. For this calculation the olivinesilicate melt model of Ford et. al [56] was selected with an oxygen fugacity of $+2.3 \log$ units above the QFM buffer, based on the equation of Borisov and Shapkin [57]. The fo 2 for the $\mathrm{Ml}$ from the scoria units was chosen through a series of "test and check" back-calculations, to identify the conditions that must have been present to produce $\mathrm{Ml}$ that have an $\mathrm{MgO}$ content that is appropriate for the $\mathrm{CaO} / \mathrm{Al}_{2} \mathrm{O}_{3}$ ratio of the $\mathrm{MI}$ when compared to the bulk rock data from the scoria lava units (Figure 10). Estimating the oxygen fugacity conditions at the time of entrapment of $\mathrm{Ml}$ from the pumice unit is more difficult due to the lack of clear textural features denoting an open or closed system. For this reason, the same conditions that were used in calculating the post-entrapment crystallisation of the GPT pumice MI were used for the scoria unit. We note that the predicted (or corrected) $\mathrm{MgO}$ concentration is sensitive to the value of oxygen fugacity used in the calculation i.e., the $\mathrm{MgO}$ concentration varies by up to $0.7 \mathrm{wt} \%$ with every log unit variation in oxygen fugacity.

As described above and illustrated in Table 3, olivine antecrysts that host $\mathrm{Ml}$ are generally un-zoned. Because of this, the average Fo content of each host olivine was used to calculate the amount of post entrapment crystallisation and the resulting composition change that a $\mathrm{MI}$ had undergone. For inclusion 4bolv01-i1 that is hosted in a zoned olivine, the average Fo content of the zone in which the Ml occurs was used, not the average of the entire crystal. The extent of disequilibrium between the $\mathrm{MI}$ and its host olivine was estimated and the amount of post-entrapment crystallisation was adjusted accordingly (Table 3). According to this correction, the pumice $\mathrm{MI}$ experienced the greatest amount of post-entrapment crystallisation, ranging from 6.7 to $15.3 \%$. The scoria 
MI underwent much less post-entrapment crystallisation, ranging from 0 to $8.6 \%$ and averaging $2.6 \%$. We note that this calculation was more successful for $\mathrm{Ml}$ that have a lower initial Mg\# (generally below Mg\#40). For more Mg-rich compositions, Petrolog3 was unable to fractionate enough olivine to reach the target Fo-content of the host. This may indicate that the fo 2 conditions varied during the period that the $\mathrm{Ml}$ were being trapped.

\subsubsection{Corrected melt inclusion chemistry}

After correction for the effects of post-entrapment crystallisation, MI compositions in the GPT typically show the same bimodal distribution in composition between the pumice and scoria units as was seen in the mineral chemistry. As discussed above, $\mathrm{Na}_{2} \mathrm{O}+\mathrm{K}_{2} \mathrm{O}$ vs. $\mathrm{SiO}_{2}$ trends place the $\mathrm{Ml}$ from the GPT pumices in the basalt field, and the MI from the GPT scoria units fall in the basalticandesite field (Figure 4). MI in the GPT pumice units have $\mathrm{Mg} \#$ ranging from 58-62 while $\mathrm{Ml}$ in the GPT scoria units are more iron-rich, with $\mathrm{Mg \#} \mathrm{47-55} \mathrm{(Table} \mathrm{2).}$

Major element compositions of MI from the GPT pumice unit showed little variation; the largest variation was a range of $2.2 \mathrm{wt} \%$ in $\mathrm{MgO}$ content. $\mathrm{Ml}$ in the GPT scoria units showed wider variation in their major element content with a 9.0 wt \% variation in $\mathrm{SiO}_{2}$ concentration, 4.76 wt \% variation in $\mathrm{Al}_{2} \mathrm{O}_{3}$, and 4.65 wt \% variation in $\mathrm{CaO}$ concentration. However, the highest $\mathrm{CaO}$ and $\mathrm{Al}_{2} \mathrm{O}_{3}$ contents and the lowest $\mathrm{SiO}_{2}$ value are found in two inclusions from horizon $\mathrm{B}$ of the scoria unit. These two MI have compositions that plot in or near the pumice unit $\mathrm{MI}$ compositions (Figures 4 and 5) and the only olivine that exhibits compositional zoning is from this unit.

As previously described, post-entrapment crystallisation may have affected the compositions of the GPT MI, resulting in large uncertainties in the $\mathrm{MgO}$ and $\mathrm{FeO}$ contents. However, the ratios of elements that are incompatible in olivine (e.g. $\mathrm{Al}_{2} \mathrm{O}_{3}, \mathrm{~K}_{2} \mathrm{O}$ ) are independent of this uncertainty and can be used along with $\mathrm{CaO}$ (which would likely contain smaller errors than $\mathrm{MgO}$ and $\mathrm{FeO}$, which may have been modified by post-entrapment crystallisation) to identify evolutionary trends of the liquids during crystallisation of olivine and other phases, including clinopyroxene (Figure 11) [15].

The trend in $\mathrm{Ml}$ compositions compared with bulk rock compositions differs between the pumice and scoria units of the GPT (Figures 11 and 12). The same bimodal distribution seen in the mineral chemistry is present in the $\mathrm{MI}$ chemistry, whereby the pumice and scoria MI cluster into two separate groups (with 2 samples from the scoria unit plotting in the pumice field). As seen in Figure 11, pumice $\mathrm{Ml}$ show a more mafic composition than the bulk rock composition of the pumice units, whereby the com-

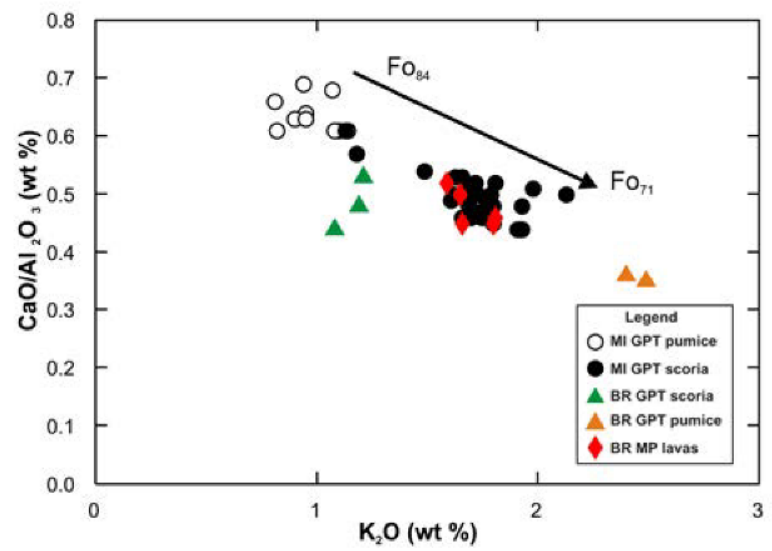

Figure 11. Relationship between $\mathrm{CaO} / \mathrm{Al}_{2} \mathrm{O}_{3}$ and $\mathrm{K}_{2} \mathrm{O}$ contents of $\mathrm{Mi}$ and bulk rock compositions of GPT products.

positions of the scoria $\mathrm{MI}$ are more evolved than the bulk rock scoria compositions. In addition, the compositions of the pumice $\mathrm{Ml}$ and pumice bulk rock are significantly different, while the scoria MI composition is more similar to the scoria bulk rock composition. However, the broadly linear trend is still present, with the compositions of $\mathrm{MI}$ from the pumices and their bulk rock compositions at either end of the trend. The decrease in $\mathrm{CaO} / \mathrm{Al}_{2} \mathrm{O}_{3}$ during crystallisation suggests that clinopyroxene was crystallising at the same time as olivine. All the lava and bulk rock compositions follow a similar trend, with $\mathrm{CaO} / \mathrm{Al}_{2} \mathrm{O}_{3}$ decreasing as $\mathrm{K}_{2} \mathrm{O}$ increases, and scoria $\mathrm{Ml}$ are similar in composition to the bulk rock lava compositions.

The same bimodal distribution and linear trend is observed in plots of $\mathrm{CaO}$ and $\mathrm{K}_{2} \mathrm{O}$ vs. $\mathrm{SiO}_{2}$ (Figure 12) where $\mathrm{CaO}$ decreases with increasing $\mathrm{SiO}_{2}$ content and $\mathrm{K}_{2} \mathrm{O}$ increases with increasing $\mathrm{SiO}_{2}$ content. Again, the pumice $\mathrm{Ml}$ and bulk rock compositions are at the ends of the trend and the scoria $\mathrm{Ml}$ compositions overlap with the lava bulk rock compositions.

\subsection{Trace Elements}

All Monte dei Porri bulk rock compositions show similar trends in REE geochemistry (Figure 13). There is a general enrichment in the LILE (especially $\mathrm{Sr}, \mathrm{K}$ and $\mathrm{Pb}$ ) and depletion in the HFSE (Nb, Ta and Ti) in almost all Monte dei Porri products, a pattern characteristic of subduction zone magmatism [58]. However, the pumices and two of the lavas show a negative $\mathrm{Pb}$ anomaly whereas the other lavas and scoria units show positive $\mathrm{Pb}$ anomalies. The overlying fields in Figure 13 show this is not a feature of any of the Aeolian arc sectors. 

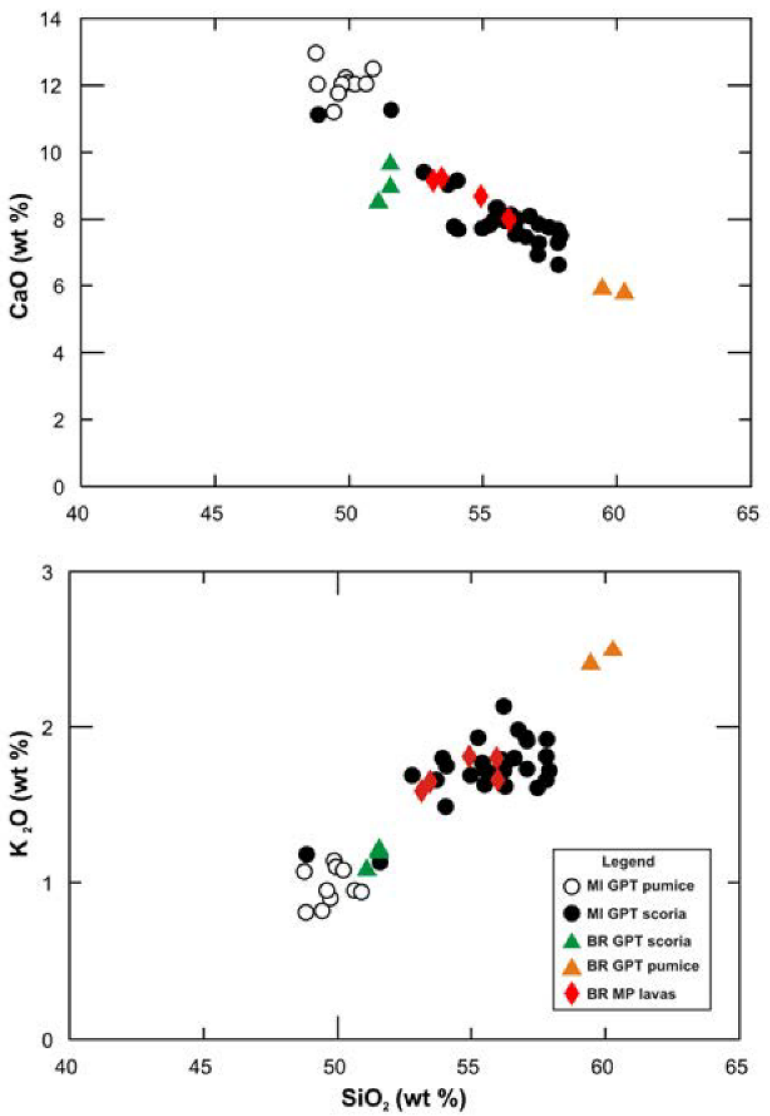

Figure 12. Relationship between $\mathrm{CaO}$ (top) and $\mathrm{K}_{2} \mathrm{O}$ (bottom) vs. $\mathrm{SiO}_{2}$ for Monte dei Porri products.

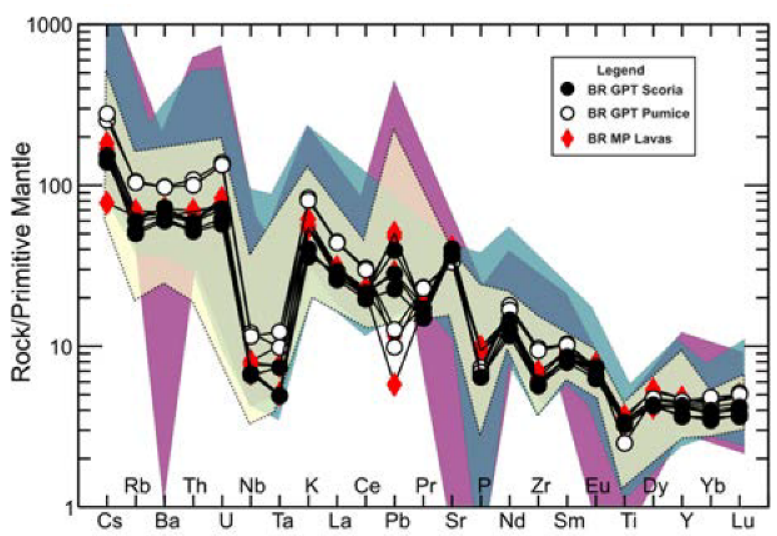

Figure 13. Primitive mantle normalised [60] incompatible trace element abundances of Monte dei Porri products sampled for this study.
In the Monte dei Porri lavas, olivine and quartz are found together in the same lava sample, sometimes directly adjacent to each other, in the felsic multi-mineralic glomerocrysts. These two phases are generally not stable together, suggesting that the lava may have sampled two different magmas. The different zoning profiles between olivine antecrysts from the lavas and olivine crystals in the glomerocrysts suggest different evolutions that are not yet clearly understood.

Although no large crustal xenoliths were identified in hand specimens, the presence of crustal xenoliths in Monte dei Porri lavas is well documented $[10,21,22,25,26]$. The glomerocrysts that contain felsic minerals and those with cumulate textures described above, may be small crustal xenoliths similar to those larger examples (many centimetres in length) described by Zanon and Nikogosian [10] (and others [10, 32, 33]) as being evidence for crustal melting and assimilation in the evolution of Monte dei Porri and other Aeolian Islands. These glomerocrysts may also represent "crystal mush zones" from the margins of the magma chamber that were entrained into the melt, or they may be evidence of mixing between a more felsic and a more mafic magma (Figure 2). Quartz and mica are also found almost exclusively in felsic glomerocrysts (or xenoliths) in the lavas, and not as an antecryst phase, so it is possible they may have formed in a more evolved melt and were introduced into the magma. This may either have been through crustal assimilation processes or magma mixing. The introduction of a more evolved magma into a less-evolved system is not unknown on Salina. As described above, the Pollara explosion crater ( 13 ka) in the north-west of the island resulted from the introduction of a silicic magma into a basaltic magma chamber [27-30]. Variations in bulk rock composition from a single eruptive unit can result from a number of different processes including the sampling of different magmas or magma chambers, or the emptying of a stratified or otherwise compositionally zoned magma chamber. As such, the compositions of $\mathrm{Ml}$ from the pumice and scoria units compared to the bulk rock compositions of their respective units provides an interesting puzzle. As seen in Figure 11 the compositions of MI in the GPT scoria unit (black circles) are more evolved than the bulk rock compositions of the scoria unit (green triangles). In contrast, the composition of $\mathrm{MI}$ in the GPT pumice unit (white circles) are more primitive than the bulk rock composition of the pumice (orange triangles). This may suggest that the more mafic olivine-hosted MI in the GPT pumice unit represent the parental magma of the GPT scoria unit and that the more acidic $\mathrm{Ml}$ in the GPT scoria unit may represent the parental magma for the 
subsequent Monte dei Porri lava eruptions. However, it is apparent that the parental magma of the GPT andesitic pumice has not been sampled in this study. This may be either because this magma represents a new magma body that intruded into the system, which indicates magma mixing, or because the olivine phases crystallised early in the magmatic evolution of the system and did not trap the more evolved magma. The GPT pumice unit contains clinopyroxene with the most evolved compositions (Figure 7) and subsequent studies of the $\mathrm{Ml}$ in the more evolved phases are expected to clarify the origin of the andesitic pumice.

The compositions of two MI from the scoria unit that plot in the pumice field are both from sample SAL10-4B collected from the centre horizon (Horizon B) of the scoria outcrop. This layer showed significant petrological differences compared to the 2 other horizons collected at the same outcrop, as it has a smaller average clast size and a different mineral assemblage (as discussed above). The reduction in olivine abundance compared to the other scoria horizons, combined with the small size and zoning (which had a higher Fo core than the other unzoned olivines in the scoria unit) indicates that they were not in equilibrium with the scoria melt in which they were found. This may indicate that the olivines in this layer were more genetically related to the olivines in the pumice layer, and may have had a similar origin, creating a link between the two units. However, the number of MI and olivine antecrysts sampled from this layer is small compared to the other layers (owing, in part, to the small number of suitable olivines that were found).

Results of this study suggest that the chemical evolution of Monte dei Porri cannot be the result of pure fractional crystallisation of a homogeneous magma body. Analysis of $\mathrm{MI}$ from the more evolved phases, as well as determination of volatile and trace element compositions of $\mathrm{MI}$ are expected to provide a more complete understanding of the origin and evolution of magmas involved in the Monte dei Porri eruptions and the plumbing system that delivered these magmas to the surface.

\section{Acknowledgements}

Luca Fedele assisted in electron microprobe analysis of the tephras and MI at Virginia Tech. We are grateful to Frank Spera (University of California - Santa Barbara) and the graduate students of Central Washington University and the University of California - Santa Barbara for assistance during sample collection. Discussions with Prof. Paola Petrosino (Università degli Studi di Napoli - Federico II), Dr. Rosario Esposito (Virginia Tech), Rita Klebesz (Università degli Studi di Napoli - Federico II) and Dr. Juliane Gross (American Museum of Natural History) were very useful during the interpretation of these data. Funding was provided by the Italian Ministry of Research and University (MUR) through the Università degli Studi di Messina PhD programme "Turismo, territorio, e l'ambiente" headed by Professor Antonia Messina. Additional funding was provided by Professor Benedetto De Vivo and the Università degli Studi di Napoli (Federico II) and by National Science Foundation grant no. EAR-1019770 awarded to Robert Bodnar.

\section{References}

[1] Roedder E., Origin and significance of magmatic inclusions. Bull. Mineral., 1979, 102, 487-510

[2] Danyushevsky L.V., Sokolov S., Falloon T.J., Melt inclusions in olivine phenocrysts; using diffusive reequilibration to determine the cooling history of a crystal, with implications for the origin of olivinephyric volcanic rocks. J. Petrol., 2002, 43, 1651-1671

[3] De Vivo B., Bodnar R.J., Melt inclusions in volcanic systems: methods, applications, and problems. Elsevier, Amsterdam, 2002

[4] Frezzotti M.L., Silicate-melt inclusions in magmatic rocks; applications to petrology. Lithos, 2001, 55, 273-299

[5] Frezzotti M.L., Peccerillo A., Bonelli R., Magma ascent rates and depths of crustal magma reservoirs beneath the Aeolian volcanic Arc (Italy): Inferences from fluid and melt inclusions in xenoliths. In: De Vivo B., Bodnar R.J.(Eds.), Developments in Volcanology. Elsevier, Amsterdam, 2003, 185-205

[6] Kamenetsky V., Clocchiatti R., Primitive magmatism of Mt. Etna; insights from mineralogy and melt inclusions. Earth Planet. Sci. Lett., 1996, 142, 553-572

[7] Kent A.J.R., Melt Inclusions in basaltic and related volcanic rocks. Rev. Mineral. Geochem., 2008, 69, 273-331

[8] Schiano P., Primitive mantle magmas recorded as silicate melt inclusions in igneous minerals. Earth-Sci. Rev., 2003, 63, 121-144

[9] Sobolev A.V. , Shimizu N., Ultra-depleted primary melt included in an olivine from the Mid-Atlantic Ridge. Nature, 1993, 363, 151-154

[10] Zanon V., Nikogosian I., Evidence of crustal melting events below the island of Salina (Aeolian arc, southern Italy). Geol. Mag., 2004, 141, 525-540

[11] Jerram D.A., Martin V.M., Understanding crystal populations and their significance through the magma plumbing system. Geol. Soc. Lond. Mem., 2008, 304, 133-148 
[12] Isole Eolie (Aeolian Islands) - UNESCO World Heritage Centre http://whc.unesco.org/en/list/ 908

[13] Davi M., Rosa R., Holtz F., Mafic enclaves in the rhyolitic products of Lipari historical eruptions; relationships with the coeval Vulcano magmas (Aeolian Islands, Italy). Bull. Volcanol., 2010, 72, 991-1008

[14] Di Martino C., Frezzotti M.-L., Lucchi F., Peccerillo A., Tranne C., Diamond L., Magma storage and ascent at Lipari Island (Aeolian archipelago, Southern Italy) at 223-81 ka: the role of crustal processes and tectonic influence. Bull. Volcanol., 2010, 72, 1061-1076

[15] Gioncada A., Clocchiatti R., Sbrana A., Bottazzi P., Massare D., Ottolini L., A study of melt inclusions at Vulcano (Aeolian Island, Italy); insights on the primitive magmas and on the volcanic feeding system. Bull. Volcanol., 1998, 60, 286-306

[16] Metrich N., Bertagnini A., Di Muro A., Conditions of magma storage, degassing and ascent at Stromboli: new insights into the volcano plumbing system with inferences on the eruptive dynamics. J. Petrol., 2010, 51, 603-626

[17] Schiano P., Clocchiatti R., Ottolini L., Sbrana A., The relationship between potassic, calc-alkaline and $\mathrm{Na}$ alkaline magmatism in South Italy volcanoes: A melt inclusion approach. Earth Planet. Sci. Lett., 2004, 220, 121-137

[18] Vannucci, R., Kobayashi, K., Nakamura, E., Tiepolo, M., Schiavi, F., Bertagnini, A., Metrich, N., Recent Stromboli (Italy): Insights into magma sources and processes from melt inclusions. Geochim. Cosmochim. Acta, 2006, 70, Supplement A667

[19] Ellam R.M., Menzies M.A., Hawkesworth C.J., Leeman W.P., Rosi M., Serri G., The transition from calcalkaline to potassic orogenic magmatism in the Aeolian Islands, southern Italy. Bull. Volcanol., 1988, 50, 386-398

[20] Gillot P.Y., Histoire volcanique des Iles Eoliennes: arc insulaire ou complexe orogenique anulaire? [Volcanic history of the Aeolian Islands: island arc or orogenic complex?] Doc. Trav. IGAL, 1987, 11 35-42 (in French)

[21] Honnorez, J., Keller J., Xenolithe in vulkanischen Gesteinen der Aeolischen Inseln (Sizilien) [Xenoliths in volcanic rocks of the Aeolian islands (Sicily)], Sicily. Geol. Rundsch., 1968, 57, 719-736 (in German)

[22] Keller J., Petrology of some volcanic rock series of the Aeolian arc, Southern Tyrrhenian Sea: Calcalkaline and shoshonitic associations. Contrib. Mineral. Petrol., 1974, 46, 29-47

[23] Peccerillo A., The Aeolian arc. In: Peccerillo, A. (Ed.),
Plio-Quaternary volcanism in Italy. Springer, Heidelberg, 2005, 173-214

[24] Barca D., Ventura G., Evoluzione vulcano-tettonica dell'isola di Salina (Arcipelago delle Eolie). [Volcano-tectonic evolution of Salina island, Aeolian Archipelago]. Mem. Soc. Geol. Ital., 1991, 47 401-415 (in Italian)

[25] Gertisser R., Keller J., From basalt to dacite: origin and evolution of the calc-alkaline series of Salina, Aeolian Arc, Italy. Contrib. Mineral. Petrol., 2000, 139, 607-626

[26] Keller J., The Island of Salina. Rend. Soc. Ital. Min. Pet., 1980, 31, 489-524

[27] Calanchi N., Rosa R., Mazzuoli R., Rossi P., Santacroce R., Ventura G., Silicic magma entering a basaltic magma chamber: eruptive dynamics and magma mixing - an example from Salina (Aeolian islands, Southern Tyrrhenian Sea). Bull. Volcanol., 1993, 55, 504-522

[28] De Rosa R., Donato P., Ventura G., Fractal analysis of mingled/mixed magmas: an example from the Upper Pollara eruption (Salina Island, southern Tyrrhenian Sea, Italy). Lithos, 2002, 65, 299-311

[29] Donato P., Behrens H., De Rosa R., Holtz F., Parat F., Crystallization conditions in the Upper Pollara magma chamber, Salina Island, Southern Tyrrhenian Sea. Mineral. Petrol., 2006, 86, 89-108

[30] Sulpizio R., De Rosa R., Donato P., The influence of variable topography on the depositional behaviour of pyroclastic density currents: The examples of the Upper Pollara eruption (Salina Island, southern Italy). J. Volcanol. Geotherm. Res., 2008, 175, 367-385

[31] Peccerillo A., Wu T.W., Evolution of calc-alkaline magmas in continental arc volcanoes; evidence from Alicudi, Aeolian Arc (southern Tyrrhenian Sea, Italy). J. Petrol., 1992, 33, 1295-1315

[32] Renzulli A., Serri G., Santi P., Mattioli M., Holm P.M., Origin of high-silica liquids at Stromboli Volcano (Aeolian Island, Italy) inferred from crustal xenoliths. Bull. Volcanol., 2001, 62, 400-419

[33] Zanon V., Frezzotti M.L., Peccerillo, A., Magmatic feeding system and crustal magma accumulation beneath Vulcano Island (Italy): Evidence from $\left(\mathrm{CO}_{2}\right)$ fluid inclusions in quartz xenoliths. J. Geophys. Res., 2003, 108, 2298-2311

[34] Bonardi G., Caggianelli A., Critelli S., Messina A., Perrone V., Acquafredda P., Carbone G., Careri G., Cirrincione R., D'Errico M., Dominici R., Festa V., lannace A., Macaione E., Mazzoli S., Notaro P., Parente M., Perri E., Piluso E., Somma R., Sonnino M., Vitale S., Geotraverse across the Calabria-Peloritani Terrane (southern Italy): Field Trip guide book P66. 
$32^{\text {nd }}$ International Geological Congress IUGS, Florence, 2004

[35] Carbone S., Messina A., Lentini F., Macaione E., Note Illustrative degli Fogli "587 - Milazzo" e "600 - Barcellona Pozzo di Gotto" alla scala 1:50.000. [Illustrative notes of foglios "587 - Milazzo" and "600 Barcellona Pozzo di Gotto" at the scale 1:50,000]. Servizio Geologico d'Italia APAT/ISPRA-Regione Siciliana. S.EL.CA., Florence (in Italian)

[36] Carbone S., Messina A., Lentini F., Note Illustrative del Foglio 601 Messina-Reggio di Calabria alla scala 1:50.000 [Illustrative notes of Foglio 601 - MessinaReggio di Calabria" at the scale 1:50,000]. Servizio Geologico d'Italia APAT/ISPRA-Regione Siciliana. S.EL.CA., Florence (in Italian)

[37] Servizio Geologico d'Italia, Foglio "601-MessinaReggio di Calabria" of the Geological Map of Italy. Scale 1:50.000. APAT-Regione Siciliana; S.EL.CA., Florence. 2008 (in Italian)

[38] Servizio Geologico d'Italia, Foglios "587-Milazzo" and "600-Barcellona Pozzo di Gotto" of the Geological Map of Italy. Scale 1:50.000. APAT/ISPRARegione Siciliana. S.EL.CA., Florence, 2011 (in Italian)

[39] lannace A., Vitale S., D'Errico M., Mazzoli S., Di Staso A., Macaione E., Messina A., Reddy S.M., Somma R., Zamparelli V., Zattin M., Bonardi G., The carbonate tectonic units of northern Calabria (Italy): a record of Apulian palaeomargin evolution and Miocene convergence, continental crust subduction, and exhumation of HP LT rocks. J. Geol. Soc., 2007, 164, 1165-1186

[40] Martin-Algarra A., Messina A., Perrone V., Russo R., Maate A., Martin-Martin M., A lost realm in the international domains of the Betic-Rif Orogen (Spain and Morocco); evidence from conglomerates and consequences for Alpine geodynamic evolution. J. Geol., 2000, 108, 447-467

[41] Perrone V., Di Staso A., Perrotta S., The evolution of the western margin and contiguous oceanic area; new problems and working hypotheses. Boll. Soc. Geol. Ital., 2008, 127, 357-373

[42] Perrone V., Martin-Algarra A., Critelli S., Decandia F.A., D’Errico M., Estevez A., lannace A., Lazzarotto A., Martin-Martin M., Martin-Rojas I., Mazzoli M., Messina A., Mongelli, G., Vitale, S., "Verrucano" and "Pseudoverrucano" in the central-western Mediterranean Alpine chains; palaeogeographical evolution and geodynamic significance. Geol. Soc. Spec. Pub., 2006, 1-43

[43] Beccaluva L.,Gabbianelli G., Lucchini F., Rossi P.L., Savelli C., Petrology and K/Ar ages of volcanics dredged from the Eolian seamounts: implications for geodynamic evolution of the southern Tyrrhenian basin. Earth Planet. Sci. Lett., 1985, 74, 187-208

[44] Anderson H. Jackson J., The deep seismicity of the Tyrrhenian Sea. Geophys. J. Roy. Astron. Soc., 1987, 91, 613-637

[45] Falsaperla S., Gurrieri L., Lombardo G., Relationship between micro-shocks recorded on the Island of Vulcano (Italy) and meteorological parameters. Pure Appl. Geophys., 1998, 152, 315-328

[46] De Astis G., Peccerillo A., Kempton P.D., La Volpe L., Wu T.W., Transition from calc-alkaline to potassiumrich magmatism in subduction environments: geochemical and $\mathrm{Sr}, \mathrm{Nd}, \mathrm{Pb}$ isotopic constraints from the island of Vulcano (Aeolian arc). Contrib. Mineral. Petrol., 2000, 139, 684-703

[47] Ellam R.M., Hawkesworth C.J., Menzies M.A., Rogers N.W., The volcanism of southern Italy: role of subduction and the relationship between potassic and sodic alkaline magmatism. J. Geophys. Res., 1989, 94, 4589-4601

[48] Gasparini C., lannaccone G., Scandone P., Scarpa R., Seismotectonics of the Calabrian Arc. Tectonophysics, 1982, 84, 267-286

[49] Beccaluva L., Rossi P.L., Serri G., Neogene to recent volcanism of the southern Tyrrhenian-Sicilian area; implications for the geodynamic evolution of the Calabrian Arc. Earth Evol. Sc., 1983, 2, 222-238

[50] Peccerillo, A., Plio-Quaternary volcanism in Italy. Springer, Heidelberg, 2005

[51] Lucchi F., Tranne C.A., De Astis G., Keller J., Losito R., Morche W., Stratigraphy and significance of Brown Tuffs on the Aeolian Islands (southern Italy). J. Volcanol. Geotherm. Res., 2008, 177, 49-70

[52] Thomas J.B., Bodnar R.J., A technique for mounting and polishing melt inclusions in small $(>1 \mathrm{~mm}$ ) crystals. Am. Mineral., 2002, 87, 1505-1508

[53] Nelson S.T., Montana A., Sieve-textured plagioclase in volcanic rocks produced by rapid decompression. The American mineralogist, 1992, 77, 1242-1249

[54] Doherty A., De Vivo B., Bodnar R., Belkin H., Messina A., Magmatic processes during the formation of Monte dei Porri Volcano, Island of Salina, Aeolian Islands, Italy. Mineral. Mag., 2011, 75, 770

[55] Danyushevsky L.V., Plechov P., Petrolog3: Integrated software for modeling crystallization processes. Geochem. Geophys. Geosyst., 2011, 12, Q07021

[56] Ford C.E., Russell D.G., Craven J.A., Fisk M.R., Olivine-liquid equilibria; temperature, pressure and composition dependence of the crystal/liquid cation partition coefficients for Mg, Fe (super 2 ) , Ca and 
Mn. J. Petrol., 1983, 24, 256-265

[57] Borisov A.A., Shapkin A.I., A new empirical equation rating $\mathrm{Fe}$ (super 3 ) / Fe (super) in magmas to their composition, oxygen fugacity, and temperature. Geochem. Int., 1990, 27, 111-116

[58] Pearce J.A., Peate D.W., Tectonic implications of the composition of volcanic arc magmas. Annu. Rev. Earth Pl. Sc., 1995, 23 251-285

[59] Peccerillo, A., Taylor, S.R. Geochemistry of Eocene calc-alkaline volcanic rocks from the Kastamonu area, northern Turkey. Contrib. Mineral. Petrol., 1976, 58(1), 63-81

[60] Sun S.-S., McDonough, W.F., Chemical and isotopic systematics of oceanic basalts: implications for manthe composition and processes. In: A.D. Saunders and M.J. Norry (Eds.), Magmatism in the Ocean Basins. Geological Society Special Publication. 1989, 313345 